\title{
OPEN In situ nitrogen mineralization and nutrient release by soil amended with black soldier fly frass fertilizer
}

\author{
Dennis Beesigamukama ${ }^{1,2,3 凶}$, Benson Mochoge ${ }^{2}$, Nicholas Korir², Changeh J. Ghemoh ${ }^{4}$, \\ Sevgan Subramanian ${ }^{1}$ \& Chrysantus M. Tanga ${ }^{1 \bowtie}$
}

Although black soldier fly frass fertilizer (BSFFF) is effective on crop performance, information on nitrogen (N) mineralization and nutrient release capacity of soils amended with BSFFF is lacking. This study utilized field incubation experiments to investigate the ammonification, nitrification, microbial populations, and quantities of nutrients released by soils amended with BSFFF and commercial organic fertilizer (SAFI) for a period equivalent to two maize cropping seasons. For the control treatment, no BSFFF or SAFI was added. Results indicated that most of the N in BSFFF amended soils was available in the ammonium form, while soils treated with SAFI had higher nitrate concentration. The BSFFF amended soils experienced shorter net immobilization periods of $\mathrm{N}$ (30-60 days) compared to SAFI treated soils (60-95 days). Increased rates of mineralization (3-10 times) and nitrification (2-4 times) were observed in soils treated with BSFFF during the second season of application. The BSFFF treated soils showed significantly higher $\mathrm{N}$, phosphorus, and magnesium release than the control. Repeated application of BSFFF led to increased $\mathrm{N}$ release by three-folds in the soil. Furthermore, soil amendment with BSFFF increased the populations of bacteria and fungi, reduced soil acidity, and increased phosphorus (two-folds) and magnesium (two-four-folds) release than SAFI treated soils. Our findings highlight the crucial role of BSFFF in improving soil health by addressing the challenges of soil acidity, phosphorus fixation and nutrient mining, which is characteristic of most tropical soils.

Crop production in sub-Saharan Africa (SSA) is hindered by low soil fertility ${ }^{1-3}$, yet mineral fertilizer use is limited by high costs and unavailability from a local source ${ }^{4}$. The use of organic fertilizers is still limited by their low availability due to other competing uses on the farm, such as feeding animals ${ }^{5,6}$ and domestic use as fuel ${ }^{7}$. Such competing uses leave little or none of the organic resources for use in crop production.

Insect frass is gaining global recognition as organic fertilizer for crop production and soil health improvement ${ }^{8-13}$. The black soldier fly (BSF) produces nutrient-rich frass fertilizer with minimal pathogens ${ }^{10,14-16}$ and chemical pollutants ${ }^{17}$. Unlike the conventional composting process, BSF-assisted composting is faster ${ }^{18}$ and more efficient at nutrient recycling ${ }^{15,19}$. In addition to its agronomic superiority ${ }^{8,10,20,21}$, the black soldier fly frass fertilizer (BSFFF) effectively improves plant health by suppressing plant pathogens ${ }^{11,22}$. These attributes make the BSFFF a quality organic fertilizer product worth integrating into farming systems of SSA, where sole mineral fertilizers are less effective due to multiple soil degradation challenges ${ }^{23,24}$.

The effectiveness of organic fertilizers in crop production is primarily influenced by the mineralization process, which determines the quantity and time in which nutrients are available for plant uptake ${ }^{25,26}$. Detailed information on the mineralization process of BSFFF amended soils is still limited. The only study on mineralization of BSFFF was done by Adin Yéton et al. ${ }^{27}$, who used a litter bag experiment that did not incorporate the frass into the soil, thereby ignoring the soil factors that influence nutrient release ${ }^{28-30}$. Furthermore, most studies on mineralization and nutrient release have focused on nitrogen only ${ }^{25,31-34}$, thus giving less attention to quantities of other macro and secondary nutrients released from organic fertilizers, which is important because organic

\footnotetext{
${ }^{1}$ International Centre of Insect Physiology and Ecology, P. O. Box 30772-00100, Nairobi, Kenya. ${ }^{2}$ Department of Agricultural Science and Technology, Kenyatta University, P.O. Box 43844-00100, Nairobi, Kenya. ${ }^{3}$ Department of Crop Production and Management, Busitema University, P.O. Box 236, Tororo, Uganda. ${ }^{4}$ Centre for African Bio-Entrepreneurship (CABE), Lavington, P.O. Box 25535-00603, Nairobi, Kenya. ${ }^{\boxplus}$ email: dbeesigamukama@ icipe.org; ctanga@icipe.org
} 


\begin{tabular}{|c|c|c|c|c|c|c|c|c|c|}
\hline \multirow[b]{2}{*}{ Parameter } & \multirow{2}{*}{$\begin{array}{l}\text { Time } \\
\text { (days) }\end{array}$} & \multicolumn{4}{|c|}{ Season 2019A (Short rains) } & \multicolumn{4}{|c|}{ Season 2019B (Long rains) } \\
\hline & & Control & BSFFF & SAFI & p value & Control & BSFFF & SAFI & p value \\
\hline \multirow{6}{*}{$\begin{array}{l}\text { Ammo- } \\
\text { nium }(\mathrm{mg} \\
\left.\mathrm{kg}^{-1}\right)\end{array}$} & 0 & $1.1 \pm 0.3 \mathrm{c}$ & $300.6 \pm 34.6 \mathrm{a}$ & $128.2 \pm 10.6 \mathrm{~b}$ & $* * *$ & $1.4 \pm 0.3 \mathrm{c}$ & $402.2 \pm 46.4 \mathrm{a}$ & $171.5 \pm 14.1 \mathrm{~b}$ & $* * *$ \\
\hline & 15 & $2.2 \pm 0.3 \mathrm{~b}$ & $207.1 \pm 75.3 \mathrm{a}$ & $96.3 \pm 5.7 \mathrm{ab}$ & * & $3.8 \pm 0.5 \mathrm{~b}$ & $353.6 \pm 128.3 \mathrm{a}$ & $164.3 \pm 9.9 \mathrm{ab}$ & * \\
\hline & 30 & $0.8 \pm 0.0 \mathrm{~b}$ & $119.9 \pm 27.6 \mathrm{a}$ & $34.0 \pm 5.6 \mathrm{~b}$ & $* *$ & $2.4 \pm 0.0 \mathrm{~b}$ & $359.7 \pm 82.9 \mathrm{a}$ & $79.3 \pm 7.5 \mathrm{~b}$ & ** \\
\hline & 60 & $50.7 \pm 18 \mathrm{ab}$ & $128.9 \pm 29.5 \mathrm{a}$ & $6.0 \pm 4.2 \mathrm{~b}$ & ${ }^{*}$ & $220.3 \pm 48.1 \mathrm{ab}$ & $490.7 \pm 112.5 \mathrm{a}$ & $22.1 \pm 15.6 \mathrm{ab}$ & ${ }^{*}$ \\
\hline & 90 & $0.8 \pm 0.0 \mathrm{~b}$ & $51.3 \pm 16.6 \mathrm{a}$ & $3.4 \pm 1.5 \mathrm{~b}$ & * & $2.1 \pm 0.1 \mathrm{~b}$ & $145.2 \pm 46.9 \mathrm{a}$ & $9.5 \pm 4.3 \mathrm{~b}$ & ${ }^{*}$ \\
\hline & 125 & $2.1 \pm 0.7 \mathrm{~b}$ & $71.9 \pm 17.6 \mathrm{a}$ & $1.8 \pm 0.6 \mathrm{~b}$ & $* * *$ & $6.4 \pm 2.0 \mathrm{~b}$ & $215.7 \pm 52.7 \mathrm{a}$ & $5.5 \pm 1.8 \mathrm{~b}$ & $* * *$ \\
\hline \multirow{6}{*}{$\begin{array}{l}\text { Nitrate (mg } \\
\left.\mathrm{kg}^{-1}\right)\end{array}$} & 0 & $0.2 \pm 0.0 \mathrm{~b}$ & $3.9 \pm 1.3 \mathrm{~b}$ & $208.1 \pm 36.3 \mathrm{a}$ & $* * *$ & $0.4 \pm 0.1 \mathrm{~b}$ & $7.5 \pm 2.5 \mathrm{~b}$ & $400.2 \pm 69.8 \mathrm{a}$ & $* * *$ \\
\hline & 15 & $2.9 \pm 0.3 \mathrm{~b}$ & $1.2 \pm 0.4 \mathrm{~b}$ & $230.3 \pm 6.7 \mathrm{a}$ & $* * *$ & $5.5 \pm 0.7 \mathrm{~b}$ & $2.4 \pm 0.7 \mathrm{~b}$ & $444.8 \pm 12.9 \mathrm{a}$ & $* * *$ \\
\hline & 30 & $3.2 \pm 0.5 \mathrm{~b}$ & $2.1 \pm 0.4 \mathrm{~b}$ & $130.7 \pm 11.8 \mathrm{a}$ & $* * *$ & $9.1 \pm 1.4 \mathrm{~b}$ & $6.1 \pm 1.3 \mathrm{~b}$ & $377.8 \pm 34.0 \mathrm{a}$ & $* * *$ \\
\hline & 60 & $9.5 \pm 2.1$ & $6.5 \pm 1.9$ & $91.5 \pm 37.1$ & ns & $14.1 \pm 3.1$ & $9.7 \pm 2.8$ & $136.0 \pm 55.1$ & ns \\
\hline & 90 & $13.9 \pm 1.9 \mathrm{~b}$ & $5.3 \pm 1.9 \mathrm{~b}$ & $234.1 \pm 47.7 \mathrm{a}$ & $* *$ & $18.1 \pm 2.5 \mathrm{~b}$ & $6.9 \pm 2.5 b$ & $305.2 \pm 62.1 \mathrm{a}$ & $* *$ \\
\hline & 125 & $8.4 \pm 2.0 \mathrm{~b}$ & $9.1 \pm 0.5 \mathrm{~b}$ & $170.2 \pm 60.3 \mathrm{a}$ & * & $14.8 \pm 3.5 \mathrm{~b}$ & $16.0 \pm 0.9 \mathrm{~b}$ & $298.8 \pm 105.8 \mathrm{a}$ & $*$ \\
\hline \multirow{6}{*}{$\begin{array}{l}\text { Ammo- } \\
\text { nium/ } \\
\text { Nitrate } \\
\text { ratio }\end{array}$} & 0 & $5.7 \pm 1.4 \mathrm{a}$ & $90.0 \pm 21.3 \mathrm{a}$ & $0.66 \pm 0.1 \mathrm{~b}$ & $* *$ & $4.0 \pm 1.0 \mathrm{~b}$ & $62.6 \pm 14.8 \mathrm{a}$ & $0.5 \pm 0.1 \mathrm{~b}$ & $* *$ \\
\hline & 15 & $0.8 \pm 0.1 \mathrm{a}$ & $165.1 \pm 10.6 \mathrm{a}$ & $0.42 \pm 0.0 \mathrm{~b}$ & $* * *$ & $0.70 \pm 0.1 \mathrm{~b}$ & $145.9 \pm 9.3 \mathrm{a}$ & $0.4 \pm 0.0 \mathrm{~b}$ & $* * *$ \\
\hline & 30 & $0.3 \pm 0.0 \mathrm{~b}$ & $57.3 \pm 3.6 \mathrm{a}$ & $0.27 \pm 0.1 \mathrm{~b}$ & $* * *$ & $0.3 \pm 0.1 \mathrm{~b}$ & $59.4 \pm 3.8 \mathrm{a}$ & $0.2 \pm 0.0 \mathrm{~b}$ & $* * *$ \\
\hline & 60 & $5.1 \pm 1.1 \mathrm{ab}$ & $22.1 \pm 7.2 \mathrm{a}$ & $0.27 \pm 0.3 \mathrm{~b}$ & * & $15.6 \pm 0.2 \mathrm{ab}$ & $56.5 \pm 18.5 a$ & $0.7 \pm 0.6 \mathrm{~b}$ & * \\
\hline & 90 & $0.1 \pm 0.0 \mathrm{~b}$ & $13.1 \pm 5.2 \mathrm{a}$ & $0.01 \pm 0.0 \mathrm{~b}$ & * & $0.1 \pm 0.0 \mathrm{~b}$ & $28.6 \pm 11.3 \mathrm{a}$ & $0.03 \pm 0.0 \mathrm{~b}$ & * \\
\hline & 125 & $0.3 \pm 0.1 \mathrm{~b}$ & $8.1 \pm 2.2 \mathrm{a}$ & $0.01 \pm 0.0 \mathrm{~b}$ & $* *$ & $0.5 \pm 0.2 \mathrm{~b}$ & $13.8 \pm 3.8 \mathrm{a}$ & $0.02 \pm 0.0 \mathrm{~b}$ & $* *$ \\
\hline
\end{tabular}

Table 1. Concentrations of ammonium and nitrates, and ammonium-nitrate ratio of soil amended with BSF frass and commercial organic fertilizers. ${ }^{* *} \mathrm{p}<0.001,{ }^{* *} \mathrm{p}<0.01,{ }^{\star} \mathrm{p}<0.05$, ns $=$ not significant at $\mathrm{p} \geq 0.05$, $\mathrm{BSFFF}=$ Black soldier fly frass fertilizer, SAFI $=$ commercial organic fertilizer, control $=$ unamended soil. Within the same row and per parameter, means ( \pm standard error) with the same letters are not significantly different at $\mathrm{p} \geq 0.05, \mathrm{n}=3$.

farming systems rely on organic fertilizers to supply all the nutrients required by the plant throughout the growth cycle. The inadequate knowledge of nutrients' release capacity other than $\mathrm{N}$ makes it difficult to solely rely on organic inputs, such as the BSFFF for nutrient supply.

Most plants consume nitrate-nitrogen $(\mathrm{N})$; therefore, understanding the ammonification and nitrification process is crucial in designing strategies for increasing the agronomic use efficiency of organic fertilizers ${ }^{35}$. Although the mineralization of different organic fertilizers has been widely studied ${ }^{26,31,36,37}$, there is inadequate research on the ammonification and nitrification processes of soils amended with BSFFF. Yet, such information would guide optimal nutrient management strategies. For example, knowledge on length of $\mathrm{N}$ immobilization period and quantity of $\mathrm{N}$ immobilized could guide the amount of inorganic $\mathrm{N}$ supplementation required to satisfy plant $\mathrm{N}$ demands ${ }^{21,31}$.

The amount of nutrients released by organic fertilizers has been chiefly estimated using aerobic incubations under controlled conditions ${ }^{34,38,39}$. However, it is important to note that fluctuations highly influence the mineralization process in environmental conditions, such as temperature, rainfall, microbial abundance, and soil moisture content ${ }^{35}$. This, therefore, makes it difficult to transfer results from laboratory experiments to the field phase since incubation conditions make the mineralization process optimal. The buried-bag technique is one of the popular methods for studying mineralization because it is easy, causes minimal disturbance of the soil, and allows investigation of nutrient dynamics of subsurface soil layers, and is thus suitable for agronomic studies ${ }^{36}$. Therefore, this study aimed to determine the rates of $\mathrm{N}$ mineralization and nitrification and the amount of macro and secondary nutrients released by soil amended with BSFFF under open field conditions to generate the information necessary for the recommendation of BSFFF into existing farming practices.

\section{Results}

Ammonium and nitrate concentrations, and ammonium/nitrate ratio. The concentrations of ammonium in soil varied significantly due to fertilizer amendments (short rainy season: $\chi^{2}=123.7, \mathrm{df}=2$, $\mathrm{p}<0.001$, long rainy season: $\chi^{2}=129.2, \mathrm{df}=2, \mathrm{p}<0.001$ ), incubation time (short rainy season: $\chi^{2}=69.6, \mathrm{df}=5$, $\mathrm{p}<0.001$, long rainy season: $\left.\chi^{2}=34.3, \mathrm{df}=5, \mathrm{p}<0.001\right)$. The interaction effect of fertilizer amendments and incubation time was also significant (short rainy season: $\chi^{2}=52.4, \mathrm{df}=10, \mathrm{p}<0.001$, long rainy season: $\chi^{2}=30.3$, $\mathrm{df}=5, \mathrm{p}<0.001$ ). Initial ammonium concentrations ranged between 1.1 and $402 \mathrm{mg} \mathrm{kg}^{-1}$, whereby the control soil and BSFFF treated soil had the lowest and highest ammonium concentrations, respectively (Table 1). The ammonium concentrations of BSFFF and commercial organic fertilizer (SAFI) treated soils were 2-287 and 4-122 times higher than those of the unamended soil, respectively. The ammonium concentration of soil amended with BSFFF and SAFI followed a decreasing trend throughout experiments. On the other hand, the ammonium concentration of unamended soil was observed to increase considerably to reach its peak values at the 60th day of incubation.

There were significant decreases in the ammonium concentration of BSFFF treated soil from initial values up to the 60th day of incubation during the short rainy season $(\mathrm{p}<0.001)$ and from the 60th to 90th day after 
incubation during the long rainy season $(\mathrm{p}<0.001)$. Soil amended with BSFFF had significantly higher ammonium concentration than the control treatment throughout experiments, except at 60 days after incubation during both seasons. Likewise, soil treated with BSFFF achieved significantly higher ammonium concentration than SAFI treatments, except at 15 and 60 days after incubation during the short and long rainy season experiments, respectively. At the end of experiments, soil amended with BSFFF had the highest ammonium concentration, which was 34 and 40 times higher than those of the control and SAFI treatments, respectively (Table 1).

Significant differences in soil nitrate concentration due to fertilizer treatments (short rainy season: $\chi^{2}=242.0$ $\mathrm{df}=2, \mathrm{p}<0.001$, long rainy season: $\left.\chi^{2}=299.0, \mathrm{df}=2, \mathrm{p}<0.001\right)$ and the interaction of treatment and incubation time (short rainy season: $\chi^{2}=23.2, \mathrm{df}=10, \mathrm{p}=0.01$, long rainy season: $\chi^{2}=31.3, \mathrm{df}=10, \mathrm{p}<0.001$ ) were observed. The effect of incubation time was significant during the long rainy season only (short rainy season: $\chi^{2}=11.0$, $\mathrm{df}=5, \mathrm{p}=0.05$, long rainy season: $\chi^{2}=13.0, \mathrm{df}=5, \mathrm{p}=0.02$ ). Initial nitrate concentrations ranged between 0.2 and $400 \mathrm{mg} \mathrm{kg}^{-1}$, while the soil in the control treatment and that treated with SAFI had the lowest and highest values, respectively (Table 1). The nitrate concentration of the control treatment increased to peak values $\left(14-18 \mathrm{mg} \mathrm{kg}^{-1}\right)$ at the 90th day after incubation during both seasons and decreased afterwards.

The nitrate concentrations of soil amended with BSFFF and SAFI did not follow a uniform trend. Soil treated with BSFFF reached peak nitrate concentration 125 days after incubation, while SAFI amended soil achieved the highest nitrate values after 90 and 15 days of incubation during the short and long rainy seasons, respectively. The nitrate concentration of soil amended with SAFI fertilizer significantly $(p=0.02)$ decreased from the 30th to 60 th day after incubation during the long rainy season. The peak nitrate concentration of SAFI treated soil was 17-27 and 26-28 times higher than those achieved using the control and BSFFF treatments, respectively. Soil amended with SAFI fertilizer maintained significantly higher nitrate concentrations than the control and BSFFF treatments, except at 60 days after incubation during both seasons. At 125 days after incubation, the nitrate concentration soil amended with SAFI was 20 and 19 times higher than those of the control and BSFFF treatments, respectively (Table 1 ).

The ammonium/nitrate ratio was significantly influenced by fertilizer treatments (short rainy season: $\chi^{2}=366.9, \mathrm{df}=2, \mathrm{p}<0.001$, long rainy season: $\chi^{2}=316.4, \mathrm{df}=2, \mathrm{p}<0.001$ ), incubation time (short rainy season: $\chi^{2}=167.6, \mathrm{df}=5, \mathrm{p}<0.001$, long rainy season: $\chi^{2}=80.2, \mathrm{df}=5, \mathrm{p}<0.001$ ) and their interactions (short rainy season: $\chi^{2}=329.3, \mathrm{df}=10, \mathrm{p}<0.001$, long rainy season: $\left.\chi^{2}=160.4, \mathrm{df}=10, \mathrm{p}<0.001\right)$. The initial ammonium/ nitrate ratio ranged between 0.5 and 90 , while SAFI and BSFFF amended soils had the lowest and highest values, respectively (Table 1). There was a spike in ammonium/nitrate ratios of the control soil to peak values at 60 days after incubation during both seasons. The same ammonium/nitrate ratio was observed in soil amended with SAFI during the long rainy season. The ammonium/nitrate ratio of soil amended with BSFFF significantly $(\mathrm{p}<0.001)$ increased to peak values at 15 after incubation and decreased significantly up to 60 days of incubation. Thereafter, the ammonium/nitrate ratio decreased until the end of experiments.

Soils amended with SAFI maintained a significantly lower ammonium/nitrate ratio than BSFFF treated soils (Table 1). The BSFFF amendment caused significantly higher ratios of ammonium/nitrate than the control treatment at 30 days $(\mathrm{F}=247.3, \mathrm{df}=2,6, \mathrm{p}<0.001), 90$ days $(\mathrm{F}=6.4, \mathrm{df}=2,6, \mathrm{p}=0.03)$ and 125 days $(\mathrm{F}=12.8, \mathrm{df}=2$, $6, p<0.001)$ after incubation during the short rainy season. Furthermore, BSFFF amended soil had significantly higher ammonium/nitrate ratio than the control during long rainy season, except at 60 days after incubation $(\mathrm{F}=7.3, \mathrm{df}=2,6, \mathrm{p}=0.03)$ (Table 1). At the end of experiments, the ammonium ratios to nitrate ranged between 0.01 and 13.8, while SAFI and BSFFF amended soils had the lowest and highest values, respectively.

Mineralization and nitrification rates. The soil nitrogen mineralization rate was significantly influenced by incubation time (short rainy season: $\chi^{2}=25.7, \mathrm{df}=4, \mathrm{p}<0.001$, long rainy season: $\chi^{2}=11.0, \mathrm{df}=4, \mathrm{p}=0.027$ ) and the interaction of incubation time and fertilizer amendment (short rainy season: $\chi^{2}=34.1, \mathrm{df}=8, \mathrm{p}<0.001$, long rainy season: $\left.\chi^{2}=45.0, \mathrm{df}=8, \mathrm{p}<0.001\right)$. The effect of fertilizer amendment was significant during the short rainy season only $\left(\chi^{2}=6.1, \mathrm{df}=2, \mathrm{p}=0.046\right)$. The fluxes of nitrogen mineralization of soil amended using different treatments are presented in Table 2.

Amendment with BSFFF triggered net mineralization rates at 60 and 125 days after incubation during the short rainy season and most of the long rainy season, except at 90 days after incubation. Soil amended with SAFI achieved net mineralization in 90 days after incubation during both seasons and at 15 days after incubation during the long rainy season. For the unamended soil, net mineralization rates were recorded at 15 and 60 days after incubation during the short rainy season, and most of the long rainy season, except at 90 days after incubation (Table 2).

Soil amended with SAFI experienced longer periods (60-95 days) of $\mathrm{N}$ immobilization during both seasons than BSFFF treatments (30-60 days) (Table 2). During the short rainy season, the highest immobilization rate $\left(-11 \mathrm{mg} \mathrm{N} \mathrm{kg}^{-1}\right.$ day $^{-1}$ ) was recorded at 30 days after incubation in soil amended with SAFI, and this was significantly $(\mathrm{p}<0.038)$ higher than that of BSFFF and control treatments. Soil amended with BSFFF experienced the highest immobilization rate $\left(-12 \mathrm{mg} \mathrm{N} \mathrm{kg}^{-1}\right.$ day $\left.^{-1}\right)$ during the long rainy season, which was not significantly different $(\mathrm{p}<0.01)$ from that of the untreated soil.

All treatments achieved peak $\mathrm{N}$ mineralization rates $\left(0.5-5.2 \mathrm{mg} \mathrm{N} \mathrm{kg}^{-1} \mathrm{day}^{-1}\right)$ between 60 and 90 days after incubation (Table 2). Soil amended using SAFI achieved the highest net mineralization rate during the short rainy season at 90 days after incubation. During the long rainy season, the unamended soil had the highest mineralization rate $\left(7.4 \mathrm{mg} \mathrm{N} \mathrm{kg}^{-1} \mathrm{day}^{-1}\right) 60$ days after incubation, which was not significantly different from that of BSFFF treatment. Generally, all treatments experienced rises in the rates of $\mathrm{N}$ mineralization during the long rainy seasons, with higher increases (three-ten folds) observed in BSFFF treated soils.

The soil nitrification rate was significantly influenced by incubation time (short rainy season: $\chi^{2}=21.6$, $\mathrm{df}=4, \mathrm{p}<0.001$, long rainy season: $\left.\chi^{2}=10.9, \mathrm{df}=4, \mathrm{p}=0.03\right)$ and the interaction of incubation time and 


\begin{tabular}{|c|c|c|c|c|c|c|c|c|c|}
\hline \multirow[b]{2}{*}{ Parameter } & \multirow[b]{2}{*}{ Time (days) } & \multicolumn{4}{|c|}{ Season 2019A (Short rains) } & \multicolumn{4}{|c|}{ Season 2019B (Long rains) } \\
\hline & & Control & BSFFF & SAFI & p value & Control & BSFFF & SAFI & p value \\
\hline \multirow{5}{*}{ Mineralization rate $\left(\mathrm{mg} \mathrm{N} \mathrm{kg}^{-1} \mathrm{day}^{-1}\right)$} & 15 & $0.25 \pm 0.02$ & $-3.18 \pm 0.07$ & $-0.65 \pm 2.34$ & ns & $0.50 \pm 0.07$ & $3.08 \pm 4.53$ & $2.49 \pm 4.11$ & ns \\
\hline & 30 & $-0.08 \pm 0.03 a$ & $-5.76 \pm 0.03 \mathrm{ab}$ & $-10.79 \pm 1.11 b$ & * & $0.15 \pm 0.12$ & $0.65 \pm 5.04$ & $-10.14 \pm 3.52$ & ns \\
\hline & 60 & $1.88 \pm 0.06$ & $0.45 \pm 0.07$ & $-2.24 \pm 1.57$ & ns & $7.43 \pm 1.68 \mathrm{a}$ & $4.49 \pm 2.77 \mathrm{a}$ & $-9.97 \pm 2.63 b$ & $* *$ \\
\hline & 90 & $-1.52 \pm 0.01 b$ & $-2.62 \pm 0.06 b$ & $4.67 \pm 2.14 \mathrm{a}$ & * & $-7.14 \pm 1.62 b$ & $-11.61 \pm 3.29 b$ & $5.22 \pm 2.66 \mathrm{a}$ & * \\
\hline & 125 & $-0.12 \pm 0.07$ & $0.70 \pm 0.05$ & $-1.87 \pm 1.65$ & ns & $0.03 \pm 0.16$ & $2.27 \pm 2.73$ & $-0.297 \pm 2.79$ & ns \\
\hline \multirow{5}{*}{$\begin{array}{l}\text { Nitrification rate (mg } \\
\left.\mathrm{NO}_{3}^{-1} \mathrm{~kg}^{-1} \text { day }^{-1}\right)\end{array}$} & 15 & $0.18 \pm 0.04$ & $-0.18 \pm 3.01$ & $1.48 \pm 1.99$ & ns & $0.34 \pm 0.04$ & $-0.35 \pm 0.13$ & $2.97 \pm 4.50$ & ns \\
\hline & 30 & $0.02 \pm 0.05 a$ & $0.06 \pm 3.64 \mathrm{a}$ & $-6.64 \pm 1.15 b$ & $* * *$ & $0.24 \pm 0.09$ & $0.25 \pm 0.07$ & $-4.47 \pm 2.87$ & ns \\
\hline & 60 & $0.21 \pm 0.66$ & $0.15 \pm 0.81$ & $-1.31 \pm 1.34$ & ns & $0.17 \pm 0.08 \mathrm{a}$ & $0.12 \pm 0.10 \mathrm{a}$ & $-8.06 \pm 2.85 b$ & * \\
\hline & 90 & $0.15 \pm 0.61$ & $-0.04 \pm 0.89$ & $4.76 \pm 2.08$ & ns & $0.13 \pm 0.02$ & $-0.09 \pm 0.08$ & $5.64 \pm 2.95$ & ns \\
\hline & 125 & $-0.16 \pm 0.09$ & $0.11 \pm 0.95$ & $-1.83 \pm 1.67$ & ns & $-0.09 \pm 0.11$ & $0.25 \pm 0.06$ & $-0.18 \pm 2.67$ & ns \\
\hline
\end{tabular}

Table 2. Nitrogen mineralization and nitrification rates of soil amended with BSF frass and commercial organic fertilizers. ${ }^{* *} \mathrm{p}<0.001,{ }^{* *} \mathrm{p}<0.01,{ }^{\star} \mathrm{p}<0.05$, ns $=$ not significant at $\mathrm{p} \geq 0.05$, BSFFF $=$ Black soldier fly frass fertilizer, $\mathrm{SAFI}=$ commercial organic fertilizer, control $=$ unamended soil. Within the same row and per parameter, means ( \pm standard error) followed by the same letters are not significantly different at $\mathrm{p} \geq 0.05, \mathrm{n}=3$.

fertilizer treatments (short rainy season: $\chi^{2}=43.2, \mathrm{df}=8, \mathrm{p}<0.001$, long rainy season: $\chi^{2}=24, \mathrm{df}=8, \mathrm{p}=0.002$ ). Table 2 presents the changes in nitrification rates during experiments. All treatments reached peak net nitrification rates 60-90 days after incubation. Soil amended with SAFI had the highest net nitrification rates (1.5-5.6 mg N kg $\mathrm{may}^{-1}$ ), which were 22-25 and 17-75 times higher than the values achieved using BSFFF and control treatments, respectively. However, amendment with SAFI depressed the nitrification rate $(-0.18$ to $-8.1 \mathrm{mg} \mathrm{N} \mathrm{kg}^{-1} \mathrm{day}^{-1}$ ) more than BSFFF treatments $\left(-0.04\right.$ to $-0.35 \mathrm{mg} \mathrm{N} \mathrm{kg}^{-1}$ day $\left.^{-1}\right)$.

Soil amended with BSFFF achieved a longer period of net nitrification ( 80 days) than SAFI amended soil (45 days) (Table 2). The net nitrification rates of soils amended with BSFFF were significantly higher than those achieved using SAFI at 30 and 60 days after incubation during the short $(\mathrm{p}<0.001)$ and long rainy seasons $(p=0.019)$, respectively. The net nitrification rates of BSFFF amended soils increased by two-four folds during the long rainy season.

Soil $\mathrm{pH}$, and populations of bacteria and fungi. The soil $\mathrm{pH}$ was significantly influenced by fertilizer treatments (short rainy season: $\chi^{2}=733.7, \mathrm{df}=2, \mathrm{p}<0.001$, long rainy season: $\chi^{2}=192.8, \mathrm{df}=2, \mathrm{p}<0.001$ ), incubation time (short rains season: $\chi^{2}=119.2, \mathrm{df}=5, \mathrm{p}<0.001$, long rainy season: $\chi^{2}=387.2, \mathrm{df}=5, \mathrm{p}<0.001$ ) and their interaction (short rainy season: $\chi^{2}=127.1, \mathrm{df}=10, \mathrm{p}<0.001$, long rainy season: $\chi^{2}=315.4, \mathrm{df}=10$, $\mathrm{p}<0.001$ ). The initial $\mathrm{pH}$ of soils amended with different fertilizer treatments ranged between 5.2 and 8.7. Thereafter, the soil $\mathrm{pH}$ decreased until the end of the experiments (Fig. 1a,d). Soil amended with BSFFF maintained significantly $(\mathrm{p}<0.001)$ higher $\mathrm{pH}$ values than control soil up to 90 days of incubation and throughout experiments for SAFI treated soil. The unamended soil had significantly higher $\mathrm{pH}$ than that of soil treated with SAFI, except at 90 days after incubation during the short rainy season (Fig. 1a). At the end of experiments, soil $\mathrm{pH}$ ranged between 4.8 and 6.2, whereby the control soil had the highest $\mathrm{pH}$ while soil amended with SAFI had the lowest $\mathrm{pH}$.

The soil bacteria population was significantly influenced by incubation time during both seasons (short rainy season: $\chi^{2}=24.7, \mathrm{df}=5, \mathrm{p}<0.001$, long rainy season: $\left.\chi^{2}=73.9, \mathrm{df}=5, \mathrm{p}<0.001\right)$ and fertilizer amendment during the short rainy season only $\left(\chi^{2}=19.9, \mathrm{df}=2, \mathrm{p}<0.001\right)$. However, the interaction of incubation time and fertilizer amendments was not significant (short rainy season: $\chi^{2}=8.9, \mathrm{df}=10, \mathrm{p}=0.541$, long rainy season: $\chi^{2}=8.1$, $\mathrm{df}=10, \mathrm{p}=0.618)$. The bacterial population significantly increased from initial values to peak levels $(9.5-10.3$ $\log _{10}$ CFU g ${ }^{-1}$ ) between 30 and 60 days after incubation and decreased afterwards (Fig. 1b,e). Soil treated with BSFFF achieved the highest bacterial populations during both seasons. Its peak bacterial population during the long rainy season was equivalent to the highest value obtained using SAFI (Fig. 1e). Amendment with BSFFF caused significantly higher bacterial populations than other treatments at 30 and 90 days during the short rainy season and at 125 days after incubation during both seasons. At the end of experiments, the bacterial populations ranged between 7.3 and $9.3 \log _{10} \mathrm{CFU} \mathrm{g}{ }^{-1}$, whereby BSFFF and control treatments had the highest and lowest values, respectively.

The different fertilizer amendments caused significant differences in soil fungi populations during the short rainy season only $\left(\chi^{2}=15.5, \mathrm{df}=2, \mathrm{p}<0.001\right)$. The effect of incubation time was significant during both seasons (short rainy season: $\chi^{2}=11.9, \mathrm{df}=5, \mathrm{p}=0.04$, long rainy season: $\chi^{2}=53.7, \mathrm{df}=5, \mathrm{p}<0.001$ ) while the interaction of fertilizer treatments and incubation time was significant during the long rainy season only $\left(\chi^{2}=18.7, \mathrm{df}=10\right.$, $\mathrm{p}=0.044$ ). Minimal changes in fungi populations were observed in the first 30 days of incubation (Fig. 1c,f). The soil fungi populations significantly increased to peak values (7.9-9.0 $\log _{10}$ CFU g ${ }^{-1}$ ) between 60 and 90 days after incubation and decreased afterwards. However, SAFI treated soil achieved peak fungi populations after 125 days during the long rainy season. Soil amended with BSFFF maintained significantly $(\mathrm{p}<0.001)$ higher fungi populations than other treatments during the entire short rainy season and 125 days after incubation during the long rainy season. At the end of the experiments, the control treatment had the lowest fungi population $\left(7.1 \log _{10}\right.$ 

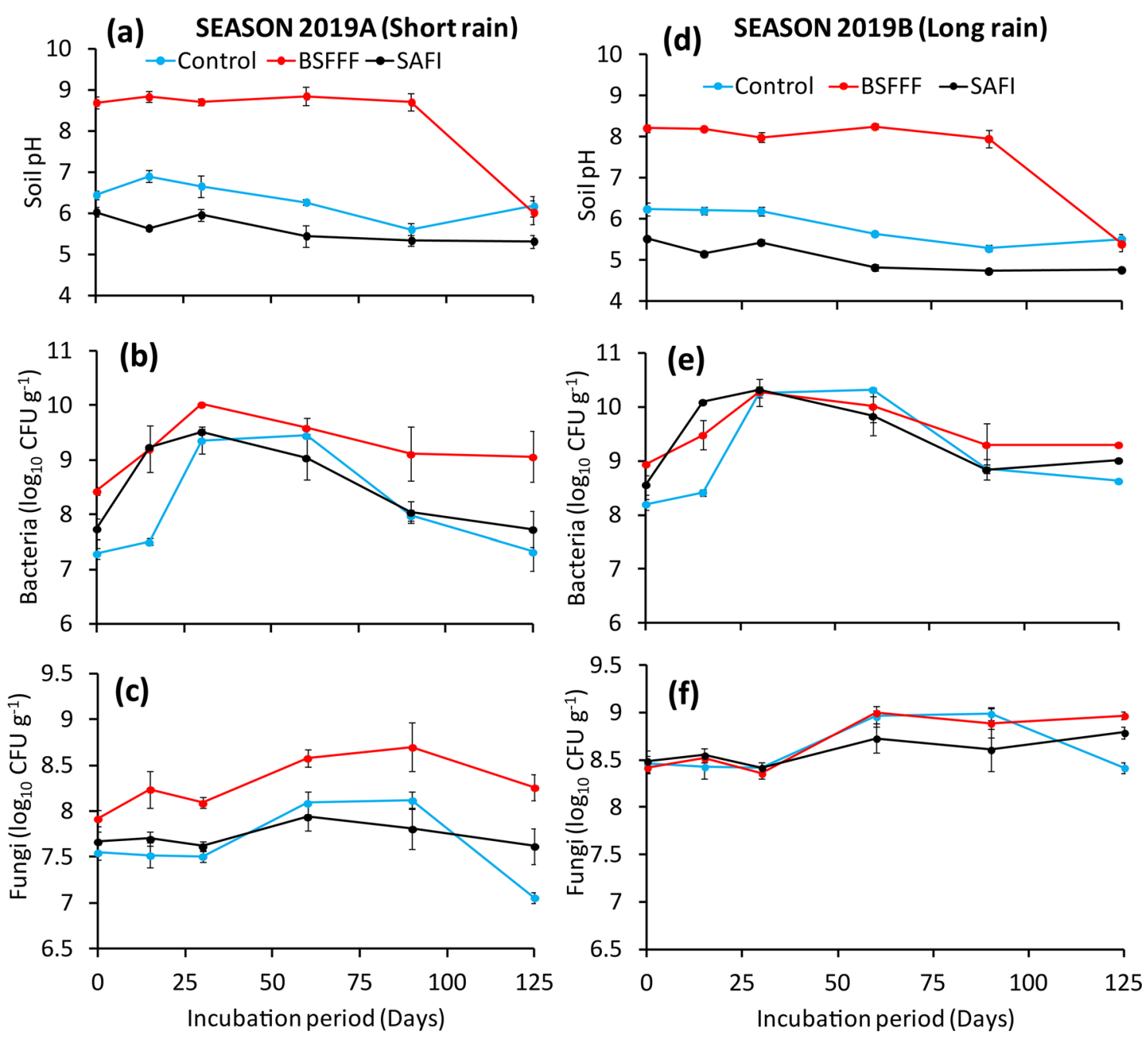

Figure 1. Changes in $\mathrm{pH}(\mathbf{a}, \mathbf{d})$, and populations of bacteria $(\mathbf{b}, \mathbf{e})$ and fungi $(\mathbf{c}, \mathbf{f})$ of soil treated with different fertilizers during the short $(\mathbf{a}-\mathbf{c})$ and long rainy $(\mathbf{d}-\mathbf{f})$ seasons incubation experiments.

CFU g ${ }^{-1}$ ) while BSFFF treated soil had the highest $\left(9.0 \log _{10} \mathrm{CFU} \mathrm{g}^{-1}\right)$. Also, soils treated with BSFFF and SAFI had a significantly $(\mathrm{p}<0.001)$ higher fungi population than the unamended soil at the end of the experiments.

Soil nutrients concentration. The total $\mathrm{N}$ concentration was significantly influenced by fertilizer amendments (short rainy season: $\chi^{2}=1011.7, \mathrm{df}=2, \mathrm{p}<0.001$, long rainy season: $\chi^{2}=1509.5, \mathrm{df}=2, \mathrm{p}<0.001$ ), incubation time (short rainy season: $\chi^{2}=143.1, \mathrm{df}=4, \mathrm{p}<0.001$, long rainy season: $\chi^{2}=30.2, \mathrm{df}=4, \mathrm{p}<0.001$ ) and their interaction (short rainy season: $\chi^{2}=261.9, \mathrm{df}=8, \mathrm{p}<0.001$, long rainy season: $\chi^{2}=231.6, \mathrm{df}=8, \mathrm{p}<0.001$ ). The total $\mathrm{N}$ concentration of soil treated with BSFFF significantly increased to peak values $(0.74-0.83 \%)$ at 30 and 60 days after incubation during the short and long rainy season, respectively, and decreased afterwards (Fig. 2a,d). On the other hand, there was minimal changes in the total $\mathrm{N}$ concentration in soil amended with SAFI during experiments, while total $\mathrm{N}$ concentration in unamended soil was observed to increase from day 60 after incubation and peaked on the 125th day.

Soils amended with BSFFF maintained significantly $(\mathrm{p}<0.001)$ higher total $\mathrm{N}$ concentration than other treatments throughout experiments. The total $\mathrm{N}$ concentration of soil treated with BSFFF was 2.5-5.4 and 2.5-4.4 times higher than soil amended with SAFI during the short and long rainy seasons, respectively. Likewise, soil amended with SAFI achieved significantly $(\mathrm{p}<0.001)$ higher total $\mathrm{N}$ concentration than the unamended soil, except at 30 days during the long rainy season and on the 125th day during both seasons. At the end of the experiments, soils treated with BSFFF had the highest $\mathrm{N}$ concentration $(0.14-0.34 \%)$, which was significantly $(\mathrm{p}<0.001)$ higher than that of the SAFI and control treatments by $149-152 \%$ and $32-44 \%$, respectively.

The concentration of available phosphorus $(\mathrm{P})$ was found to vary significantly due to fertilizer amendments (short rainy season: $\chi^{2}=5920.2, \mathrm{df}=2, \mathrm{p}<0.001$, long rainy season: $\chi^{2}=6128.9, \mathrm{df}=2, \mathrm{p}<0.001$ ), incubation time (short rainy season: $\chi^{2}=55.1, \mathrm{df}=4, \mathrm{p}<0.001$, long rainy season: short rainy season: $\chi^{2}=68.0, \mathrm{df}=4, \mathrm{p}<0.001$ ) and the interaction effect of fertilizers and incubation time (short rainy season: short rainy season: $\chi^{2}=45.4$, $\mathrm{df}=8, \mathrm{p}<0.001$, long rainy season: short rainy season: $\left.\chi^{2}=43.3, \mathrm{df}=8, \mathrm{p}<0.001\right)$. Initial $\mathrm{P}$ concentration ranged 

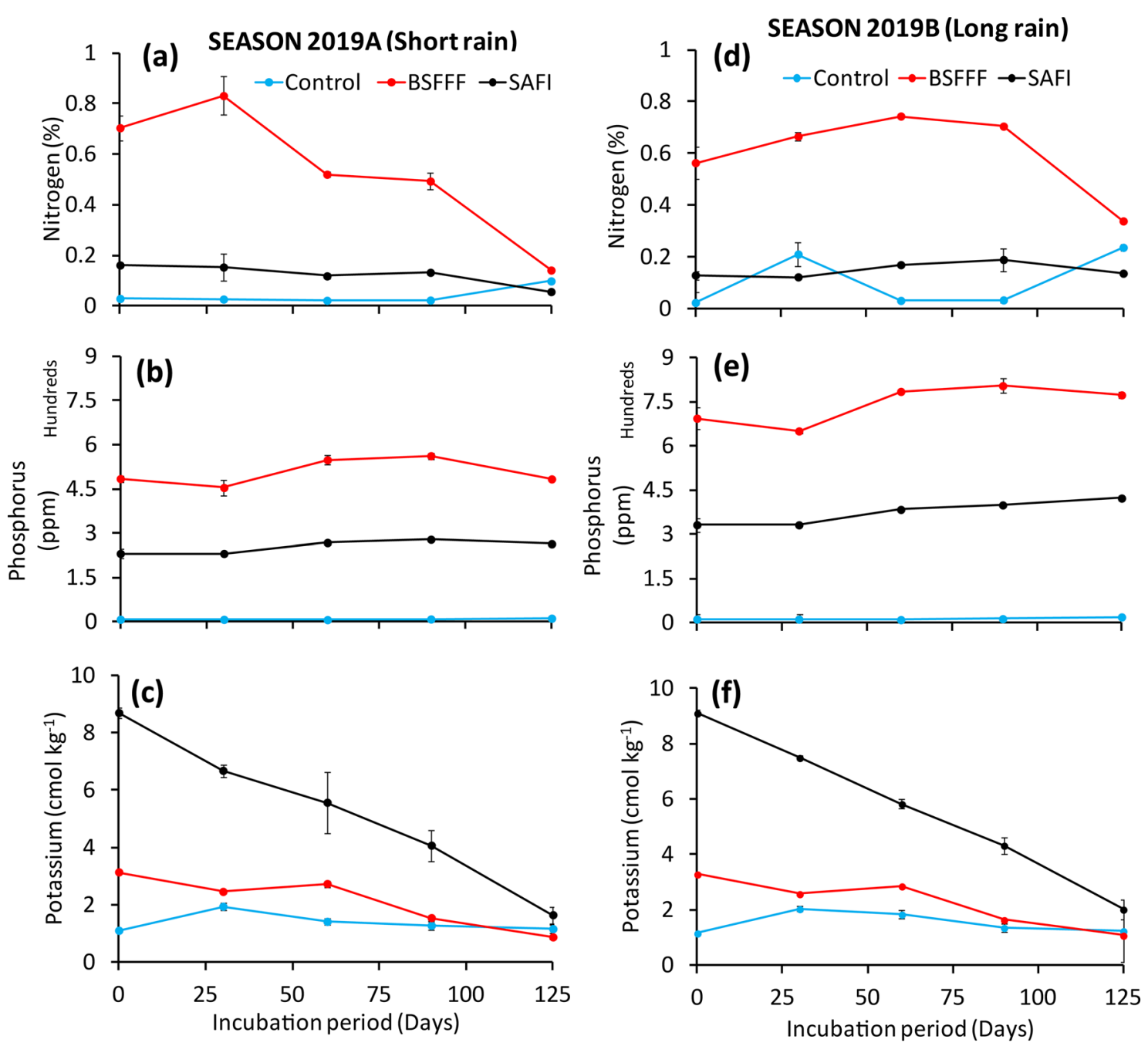

Figure 2. Effects of different fertilizers on concentrations of total nitrogen (a,d), available phosphorus $(\mathbf{b}, \mathbf{e})$ and exchangeable potassium $(\mathbf{c}, \mathbf{f})$ of soils during the short $(\mathbf{a}-\mathbf{c})$ and long rainy $(\mathbf{d}-\mathbf{f})$ seasons incubation experiments.

between 8 and 694 ppm and significantly $(\mathrm{p}<0.001)$ increased to peak values $(279-804 \mathrm{ppm})$ between 90 and 125 days after incubation (Fig. 2b,e).

All fertilizer treatments maintained significantly $(\mathrm{p}<0.001)$ higher $\mathrm{P}$ levels than the control treatment throughout experiments. The $\mathrm{P}$ concentration of the control soil did not vary significantly during experiments. The P concentration of soil treated with BSFFF was significantly $(\mathrm{p}<0.001)$ higher than that of SAFI treatment by 1.8-2.1 times. At the end of experiments, the P concentration of soil treated with BSFFF was about $83 \%$ higher than that of SAFI treatment $(p<0.001)$.

The concentrations of exchangeable potassium $(\mathrm{K})$ also varied significantly due to fertilizer amendments (short rainy season: $\chi^{2}=384.8, \mathrm{df}=2, \mathrm{p}<0.001$, long rainy season: $\chi^{2}=386.7, \mathrm{df}=2, \mathrm{p}<0.001$ ), incubation time (short rainy season: $\chi^{2}=154.7, \mathrm{df}=4, \mathrm{p}<0.001$, long rainy season: $\chi^{2}=140.9, \mathrm{df}=4, \mathrm{p}<0.001$ ) and their interaction (short rainy season: $\chi^{2}=127.6, \mathrm{df}=8, \mathrm{p}<0.001$, long rainy season: $\chi^{2}=118.7, \mathrm{df}=8, \mathrm{p}<0.001$ ). The initial $\mathrm{K}$ concentration ranged between 1.1 and $9.1 \mathrm{cmol} \mathrm{kg}^{-1}$ from where it decreased throughout experiments, with the highest decreases observed in SAFI treated soils (Fig. 2c,f). Soil amended with SAFI maintained significantly $(\mathrm{p}<0.001)$ higher $\mathrm{K}$ levels than other treatments, except at 125 days during the long rainy season. Soil treated with BSFFF had significantly $(\mathrm{p}<0.001)$ higher K concentration than the control soil up to 90 days of incubation. The final $\mathrm{K}$ concentration of SAFI treated soil $\left(1.6-2.0 \mathrm{cmol} \mathrm{kg}^{-1}\right)$ was $87-89 \%$ and $42-63 \%$ higher than those achieved using BSFFF and the control treatment, respectively.

The exchangeable calcium (Ca) ions varied significantly due to fertilizer amendments during experiments (short rainy season: $\chi^{2}=59.9, \mathrm{df}=2, \mathrm{p}<0.001$, long rainy season: $\chi^{2}=48.9, \mathrm{df}=2, \mathrm{p}<0.001$ ) and incubation time (short rainy season: $\chi^{2}=19.9, \mathrm{df}=4, \mathrm{p}<0.001$, long rainy season: $\chi^{2}=92.2, \mathrm{df}=4, \mathrm{p}<0.001$ ) but the interaction effects were not significant (short rainy season: $\chi^{2}=6.3, \mathrm{df}=8, \mathrm{p}=0.61$, long rainy season: $\chi^{2}=14.0$, $\mathrm{df}=8, \mathrm{p}=0.08$ ). The Ca concentration decreased to minimum values at 90 and 60 days of incubation during the short and long rainy seasons, respectively and increased thereafter (Table 3). Soil amended with SAFI achieved 


\begin{tabular}{|c|c|c|c|c|c|c|c|c|c|}
\hline \multirow[b]{2}{*}{ Parameter } & \multirow[b]{2}{*}{ Time (days) } & \multicolumn{4}{|c|}{ Season 2019A (Short rains) } & \multicolumn{4}{|c|}{ Season 2019B (Long rains) } \\
\hline & & \begin{tabular}{|l|} 
Control \\
\end{tabular} & BSFFF & SAFI & p value & Control & BSFFF & SAFI & p value \\
\hline \multirow{5}{*}{$\begin{array}{l}\text { Calcium } \\
\left(\mathrm{cmol} \mathrm{kg}^{-1}\right)\end{array}$} & 0 & $1.10 \pm 0.04 \mathrm{a}$ & $0.84 \pm 0.02 \mathrm{~b}$ & $1.04 \pm 0.04 \mathrm{a}$ & $* *$ & $0.76 \pm 0.03 a$ & $0.58 \pm 0.01 \mathrm{~b}$ & $0.73 \pm 0.03 a$ & $* *$ \\
\hline & 30 & $1.08 \pm 0.03 \mathrm{a}$ & $0.82 \pm 0.01 \mathrm{~b}$ & $1.11 \pm 0.03 \mathrm{a}$ & $* * *$ & $0.75 \pm 0.02 \mathrm{a}$ & $0.56 \pm 0.00 \mathrm{~b}$ & $0.77 \pm 0.02 \mathrm{a}$ & $* * *$ \\
\hline & 60 & $0.96 \pm 0.02 \mathrm{ab}$ & $0.71 \pm 0.02 \mathrm{~b}$ & $1.04 \pm 0.13 \mathrm{a}$ & ns & $0.66 \pm 0.02 \mathrm{ab}$ & $0.49 \pm 0.01 \mathrm{~b}$ & $0.73 \pm 0.09 \mathrm{a}$ & * \\
\hline & 90 & $0.81 \pm 0.01 \mathrm{ab}$ & $0.53 \pm .006 \mathrm{~b}$ & $1.02 \pm 0.06 \mathrm{a}$ & * & $1.05 \pm 0.01 \mathrm{ab}$ & $0.69 \pm 0.07 \mathrm{~b}$ & $1.32 \pm 0.20 \mathrm{a}$ & * \\
\hline & 125 & $0.97 \pm 0.02$ & $0.80 \pm 0.01$ & $1.16 \pm 0.16$ & ns & $1.06 \pm 0.02$ & $0.87 \pm 0.01$ & $1.26 \pm 0.18$ & ns \\
\hline \multirow{5}{*}{$\begin{array}{l}\text { Magnesium } \\
\left(\mathrm{cmol} \mathrm{kg}^{-1}\right)\end{array}$} & 0 & $0.78 \pm 0.04 \mathrm{~b}$ & $2.86 \pm 0.11 \mathrm{a}$ & $1.06 \pm 0.02 \mathrm{~b}$ & $* * *$ & $0.65 \pm 0.03 \mathrm{~b}$ & $2.37 \pm 0.09 \mathrm{a}$ & $0.89 \pm 0.02 \mathrm{~b}$ & $* * *$ \\
\hline & 30 & $0.83 \pm 0.02 \mathrm{c}$ & $2.84 \pm 0.01 \mathrm{a}$ & $1.09 \pm 0.06 \mathrm{~b}$ & $* * *$ & $0.70 \pm 0.01 \mathrm{c}$ & $2.36 \pm 0.01 \mathrm{a}$ & $0.91 \pm 0.05 \mathrm{~b}$ & $* * *$ \\
\hline & 60 & $0.81 \pm 0.10 \mathrm{~b}$ & $3.10 \pm 0.21 \mathrm{a}$ & $0.93 \pm 0.02 \mathrm{~b}$ & $* * *$ & $0.68 \pm 0.04 \mathrm{~b}$ & $2.57 \pm 0.08 \mathrm{a}$ & $0.78 \pm 0.18 \mathrm{~b}$ & $* * *$ \\
\hline & 90 & $0.71 \pm 0.02 \mathrm{~b}$ & $2.56 \pm 0.12 \mathrm{a}$ & $0.89 \pm 0.14 \mathrm{~b}$ & $* * *$ & $0.58 \pm 0.01 \mathrm{~b}$ & $2.11 \pm 0.10 \mathrm{a}$ & $0.74 \pm 0.14 \mathrm{~b}$ & $* * *$ \\
\hline & 125 & $0.68 \pm 0.02 \mathrm{~b}$ & $2.85 \pm 0.03 \mathrm{a}$ & $0.78 \pm 0.19 b$ & $* * * *$ & $0.55 \pm 0.02 \mathrm{a}$ & $2.35 \pm 0.02 \mathrm{a}$ & $0.64 \pm 0.15 b$ & $* * *$ \\
\hline
\end{tabular}

Table 3. Concentrations of exchangeable calcium and magnesium in soil alone and soil amended by BSF frass and commercial organic fertilizers during the short and long rainy seasons. ${ }^{* *} \mathrm{p}<0.001,{ }^{* *} \mathrm{p}<0.01,{ }^{*} \mathrm{p}<0.05$, $\mathrm{ns}=$ not significant at $\mathrm{p} \geq 0.05 \mathrm{BSFFF}=$ Black soldier fly frass fertilizer, SAFI $=$ commercial organic fertilizer, control $=$ unamended soil. Within the same row and per parameter, means ( \pm standard error) followed by the same letters are not significantly different at $\mathrm{p} \geq 0.05, \mathrm{n}=3$.

\begin{tabular}{|c|c|c|c|c|c|c|c|c|c|c|}
\hline \multirow[b]{4}{*}{ Treatment } & \multicolumn{5}{|c|}{ Season 2019A (Short rains) } & \multicolumn{5}{|c|}{ Season 2019B (Long rains) } \\
\hline & \multirow{2}{*}{$\begin{array}{l}\text { Mineral } \\
\text { nitrogen }\end{array}$} & \multirow{2}{*}{$\begin{array}{l}\text { Available } \\
\text { phosphorus }\end{array}$} & \multicolumn{3}{|c|}{ Exchangeable cations } & \multirow{2}{*}{$\begin{array}{l}\text { Mineral } \\
\text { nitrogen }\end{array}$} & \multirow{2}{*}{$\begin{array}{l}\text { Available } \\
\text { phosphorus }\end{array}$} & \multicolumn{3}{|c|}{ Exchangeable cations } \\
\hline & & & Potassium & Calcium & Magnesium & & & Potassium & Calcium & Magnesium \\
\hline & \multicolumn{10}{|l|}{$\left(\mathrm{kg} \mathrm{ha}^{-1}\right)$} \\
\hline Control & $27.9 \pm 6.1 \mathrm{~b}$ & $32.1 \pm 6.5 \mathrm{c}$ & $1197.4 \pm 173.1$ & $516.7 \pm 19.3$ & $215.5 \pm 10.5 \mathrm{~b}$ & $56.1 \pm 12.0 \mathrm{~b}$ & $51.0 \pm 10.4 \mathrm{c}$ & $1277.1 \pm 184.4$ & $561.6 \pm 20.9$ & $174.6 \pm 8.7 \mathrm{c}$ \\
\hline BSFFF & $215.2 \pm 9.0 \mathrm{ab}$ & $1276.2 \pm 38.6 \mathrm{~b}$ & $899.6 \pm 101.2$ & $423.1 \pm 5.6$ & $902.2 \pm 16.7 \mathrm{a}$ & $616.0 \pm 147.7 \mathrm{a}$ & $2039.8 \pm 61.7 \mathrm{a}$ & $1111.0 \pm 125.3$ & $460.1 \pm 6.1$ & $743.9 \pm 13.8 \mathrm{a}$ \\
\hline SAFI & $446.4 \pm 146.7 \mathrm{a}$ & $696.2 \pm 6.2 \mathrm{a}$ & $1692.3 \pm 316.7$ & $608.3 \pm 76.0$ & $245.2 \pm 52.3 \mathrm{~b}$ & $389.2 \pm 127.8 \mathrm{ab}$ & $1112.6 \pm 9.9 \mathrm{~b}$ & $2081.8 \pm 389.1$ & $660.6 \pm 82.4$ & $408.5 \pm 91.3 \mathrm{~b}$ \\
\hline $\mathrm{p}$ value & * & $* * *$ & ns & Ns & $* * *$ & * & $* * *$ & ns & ns & $* * *$ \\
\hline
\end{tabular}

Table 4. Nutrients released from unamended soil and soils amended with organic fertilizers during the short and long rains cropping seasons. ${ }^{* *} \mathrm{p}<0.001,{ }^{* *} \mathrm{p}<0.01,{ }^{*} \mathrm{p}<0.05$, ns $=$ nonsignificant at $\mathrm{p} \geq 0.05$, BSFFF $=$ Black soldier fly frass fertilizer, SAFI = commercial organic fertilizer, control = unamended soil. Within the same column and per parameter, means ( \pm standard error) followed by the same letters are not significantly different at $\mathrm{p} \geq 0.05, \mathrm{n}=3$.

significantly $(\mathrm{p}<0.001)$ higher Ca concentration than BSFFF treatments by $24-96$ and $26-91 \%$ during short and long rainy seasons, respectively.

The control treatment attained significantly $(\mathrm{p}<0.001)$ higher Ca concentration than BSFFF amended soil during the first 30 days of incubation. At the end of experiments, the Ca concentration did not vary significantly (long rainy season: $\mathrm{p}=0.096$, long rains season: $\mathrm{p}=0.098$ ), but SAFI amended soils had the highest. At the same time, BSFFF treated soil had the lowest $\mathrm{Ca}$ concentration.

The exchangeable magnesium $(\mathrm{Mg})$ ions in the soil also varied significantly due to fertilizer amendments (short rainy season: $\chi^{2}=1341.0 \mathrm{df}=2, \mathrm{p}<0.001$, long rainy season: $\chi^{2}=1339.4, \mathrm{df}=2, \mathrm{p}<0.001$ ) and incubation time (short rainy season: $\chi^{2}=12.0, \mathrm{df}=4, \mathrm{p}=0.018$, long rains season: $\chi^{2}=14.7, \mathrm{df}=4, \mathrm{p}=0.005$ ) during both seasons, but their interactions were not significant (short rainy season: $\chi^{2}=10.8, \mathrm{df}=8, \mathrm{p}=0.213$, long rainy season: $\left.\chi^{2}=10.9, \mathrm{df}=4, \mathrm{p}=0.209\right)$. Initial $\mathrm{Mg}$ concentrations ranged between 0.78 and $2.86 \mathrm{cmol} \mathrm{kg}^{-1}$, while the control and BSFFF treatments had the lowest and highest Mg concentrations, respectively (Table 3 ).

The Mg concentration increased to peak values of 0.68 to $3.10 \mathrm{cmol} \mathrm{kg}^{-1}$ between 30 and 60 days of incubation, after which the concentrations kept decreasing up to the end of the experiments. The $\mathrm{Mg}$ concentration of soil amended with BSFFF was 2.6-3.7 and 3.4-4.3 times higher than those of SAFI treated and unamended soil, respectively. Also, soils treated with BSFFF maintained significantly $(\mathrm{p}<0.001)$ higher $\mathrm{Mg}$ concentration than other treatments, except the control at 125 days of incubation during the long rainy season. At the end of the experiments, soil treated with BSFFF had the highest $\mathrm{Mg}$ concentration $\left(2.4-2.9 \mathrm{cmol} \mathrm{kg}^{-1}\right)$, which was 3.7 and 4.3 times higher than those of SAFI and control treatments.

Nutrients released by unamended soil and soils amended with organic fertilizers. The amount of $\mathrm{N}$ (short rainy season: $\mathrm{F}=5.5, \mathrm{df}=2,6, \mathrm{p}=0.044$, long rainy season: $\mathrm{F}=6.2, \mathrm{df}=2,6, \mathrm{p}=0.035$ ), that of available $\mathrm{P}$ (short rainy season: $\mathrm{F}=740.9, \mathrm{df}=2,6, \mathrm{p}<0.001$, long rainy season: $\mathrm{F}=740.2, \mathrm{df}=2,6, \mathrm{p}<0.0001$ ) and exchangeable $\mathrm{Mg}$ (short rainy season: $\mathrm{F}=135.7, \mathrm{df}=2,6, \mathrm{p}<0.001$, long rainy season: $\mathrm{F}=28.6, \mathrm{df}=2,6, \mathrm{p}<0.001$ ) released by the unamended soil and soils amended with different organic fertilizers varied significantly during the experiments (Table 4). However, the quantities of $\mathrm{K}$ (short rainy season: $\mathrm{F}=3.4, \mathrm{df}=2,6, \mathrm{p}=0.102$, long rainy 


\begin{tabular}{|c|c|c|c|c|c|c|c|c|c|c|c|c|c|c|}
\hline Parameter & $\begin{array}{l}\mathrm{pH}(1: 2.5 \\
\text { water) }\end{array}$ & \begin{tabular}{|l|}
$\begin{array}{l}\text { Bulk } \\
\text { density }\end{array}$ \\
$\left(\mathrm{g} \mathrm{cm}^{-3}\right)$ \\
\end{tabular} & \begin{tabular}{|l} 
Mineral N \\
$\left(\mathrm{mg} \mathrm{kg}^{-1}\right)$
\end{tabular} & $\begin{array}{l}\text { Total N } \\
(\%)\end{array}$ & TOC & SOM & $\begin{array}{l}\text { Available P } \\
(\mathrm{ppm})\end{array}$ & \multicolumn{3}{|c|}{$\begin{array}{l}\text { Exchangeable cations (cmol } \\
\mathrm{kg}^{-1} \text { ) }\end{array}$} & $\%$ sand & $\%$ clay & $\%$ silt & $\begin{array}{l}\text { Textural } \\
\text { class }\end{array}$ \\
\hline \multicolumn{15}{|c|}{ Experimental soil } \\
\hline \multirow[b]{2}{*}{ Parameter } & \multirow{2}{*}{$\begin{array}{l}\text { Moisture } \\
(\%)\end{array}$} & \multirow[b]{2}{*}{ pH } & \multirow{2}{*}{$\begin{array}{l}\mathrm{EC}(\mathrm{mS} \\
\left.\mathrm{cm}^{-1}\right)\end{array}$} & Ammonium & Nitrate & TOC & Total N & Total P & Total K & Total Ca & Total Mg & \multirow[b]{2}{*}{$\mathrm{C} / \mathrm{N}$ ratio } & & \\
\hline & & & & \multicolumn{2}{|l|}{$\left(\mathrm{mg} \mathrm{kg}^{-1}\right)$} & \multicolumn{6}{|l|}{$(\%)$} & & & \\
\hline \multicolumn{15}{|c|}{ Organic fertilizers } \\
\hline SAFI & 29.8 & 6.4 & 6.1 & 39.4 & 92.3 & 45.1 & 3.0 & 1.23 & 1.49 & 0.29 & 0.43 & 15.0 & & \\
\hline
\end{tabular}

Table 5. Selected physical and chemical characteristics of the experimental soil, and organic fertilizers. TOC total organic carbon, $S O M$ soil organic matter, BSFFF black soldier fly frass fertilizer, SAFI commercial organic fertilizer, $\mathrm{n}=3$.

season: $\mathrm{F}=4.0, \mathrm{df}=2,6, \mathrm{p}=0.078$ ) and $\mathrm{Ca}$ (short rainy season: $\mathrm{F}=4.2, \mathrm{df}=2,6, \mathrm{p}=0.073$, long rainy season: $\mathrm{F}=4.1, \mathrm{df}=2,6, \mathrm{p}=0.074$ ) released were not significantly influenced by fertilizer amendments.

Soil amended with SAFI and BSFFF released significantly $(\mathrm{p}<0.001)$ higher $\mathrm{N}$ than unamended soil during the short and long rainy seasons, respectively (Table 4). The $\mathrm{N}$ released by soil treated with SAFI and BSFFF was 7-16 times and 8-11 times higher than $\mathrm{N}$ released by the control soil, respectively. Soils treated with SAFI released $107 \%$ higher $\mathrm{N}$ than BSFFF treated soil during the short rainy season. On the other hand, soil treated with BSFFF released the highest $\mathrm{N}$ during the long rainy season, 58 and 998\% higher than SAFI amended soil and the control soil, respectively.

The quantity of $\mathrm{P}$ released by BSFFF amended soils was significantly $(\mathrm{p}<0.001)$ higher than those of SAFI and control treatments by about two- and forty-folds, respectively. In contrast, the P released by soil treated with SAFI was 22 times higher than that released by the control soil (Table 4). Soil treated with SAFI had the highest $\mathrm{K}$, which was 1.9 times and 1.4-1.6 times higher than those of BSFFF and control treatments, respectively. The Ca released by soil amended with SAFI was 44 and $18 \%$ higher than that released by BSFFF and the control treatments, respectively.

The highest quantity of $\mathrm{Mg}$ was released by soil amended with BSFFF, and this was significantly $(\mathrm{p}<0.001)$ higher than those of SAFI and control treatments by $82-268 \%$ and $319-326 \%$, respectively (Table 4 ). However, soil amendment with SAFI released significantly higher $\mathrm{Mg}$ than the control treatment.

\section{Discussion}

The patterns of soil mineralization and nitrification rates, and seasonal differences observed during this study (Tables 1 and 2) have been previously reported ${ }^{35,40}$. The high ammonium and low nitrate concentrations observed in BSFFF treated soil could be attributed to the quality of the frass fertilizer used in the study (Table 5). Ammonium nitrogen is one of the major $\mathrm{N}$ fractions that influence $\mathrm{N}$ released from organic fertilizers ${ }^{32}$. The BSF frass contains high levels of ammonium nitrogen ${ }^{15,18,41}$, which requires time to be converted into plant-available form $\left(\mathrm{NO}_{3}{ }^{-}\right)$through mineralization and nitrification processes. At the same time, ammonium is preferred by soil microorganisms, making it prone to immobilization ${ }^{25,42}$. The high $\mathrm{pH}$ values (8.0-8.8) (Fig. 1a,d) observed in soil amended with BSFFF could have triggered gaseous losses through ammonia volatilization and reduced the nitrification process as indicated by the higher ratios of ammonium to nitrate ${ }^{43}$. The $\mathrm{pH}$ values above 7.5 favour nitrogen loss through ammonia volatilization ${ }^{44}$ because an increase in $\mathrm{pH}$ has been shown to increase the dissociation of ammonium to ammonia gas, thus shifting the equilibrium to ammonia, which eventually evaporates ${ }^{45}$.

The higher soil nitrate concentration (Table 1) and nitrification rates (Table 2) realized using SAFI could be partly attributed to initially low ammonium/nitrate ratio (Table 1) and lower soil pH values $(<7.0)$ during experiments (Fig. 1a,d). This agrees with previous studies that reported higher autotrophic nitrification under conditions of low ammonium and low $\mathrm{pH}^{46}$. Therefore, the low nitrification rates observed in BSFFF amended soil could also be attributed to the toxic effects of high ammonium and alkaline conditions on the enzymatic activities of nitrifying bacteria ${ }^{47}$. Although, the current studies found slightly higher populations of bacteria (Fig. 1b,e) and fungi (Fig. 1c,f) in BSFFF treated soil than SAFI treatments, the strains of nitrifiers present, their functional roles, and influence on enzymatic activities were not determined. Future studies would be necessary to investigate the effect of the BSFFF amendment on the abundance and diversity of nitrifying bacteria, and enzymatic activities, to generate accurate conclusions on the nitrification process.

Conversely, the net $\mathrm{N}$ immobilization associated with SAFI could be attributed to the lignin and polyphenols present in the biochar used to make SAFI ${ }^{31,48,49}$. The recalcitrant carbon in biochar is resistant to microbial decomposition and consequently causes delays in $\mathrm{N}$ mineralization ${ }^{50,51}$. The low total $\mathrm{N}$ concentration, such as that observed in soil amended with SAFI (Fig. 2a,d), has also been found to stimulate immobilization and slow down $\mathrm{N}$ release ${ }^{40}$. Our sister paper ${ }^{21}$ suggested supplementation with mineral $\mathrm{N}$ fertilizers to compensate for $\mathrm{N}$ immobilization and improve synchrony of $\mathrm{N}$ supply for optimal crop production. This agrees with Kaleem Abbasi and $\mathrm{Khaliq}^{34}$, who reported accelerated mineralization and nitrification rates in soils amended with a combination of mineral $\mathrm{N}$ and organic fertilizers. However, the higher and net positive values of nitrification and nitrification rates observed during the long rains (Table 2) suggest that continued amendment of soil using $\mathrm{BSFFF}$ could gradually increase the nitrification rate and mineral $\mathrm{N}$ release for plant uptake. 

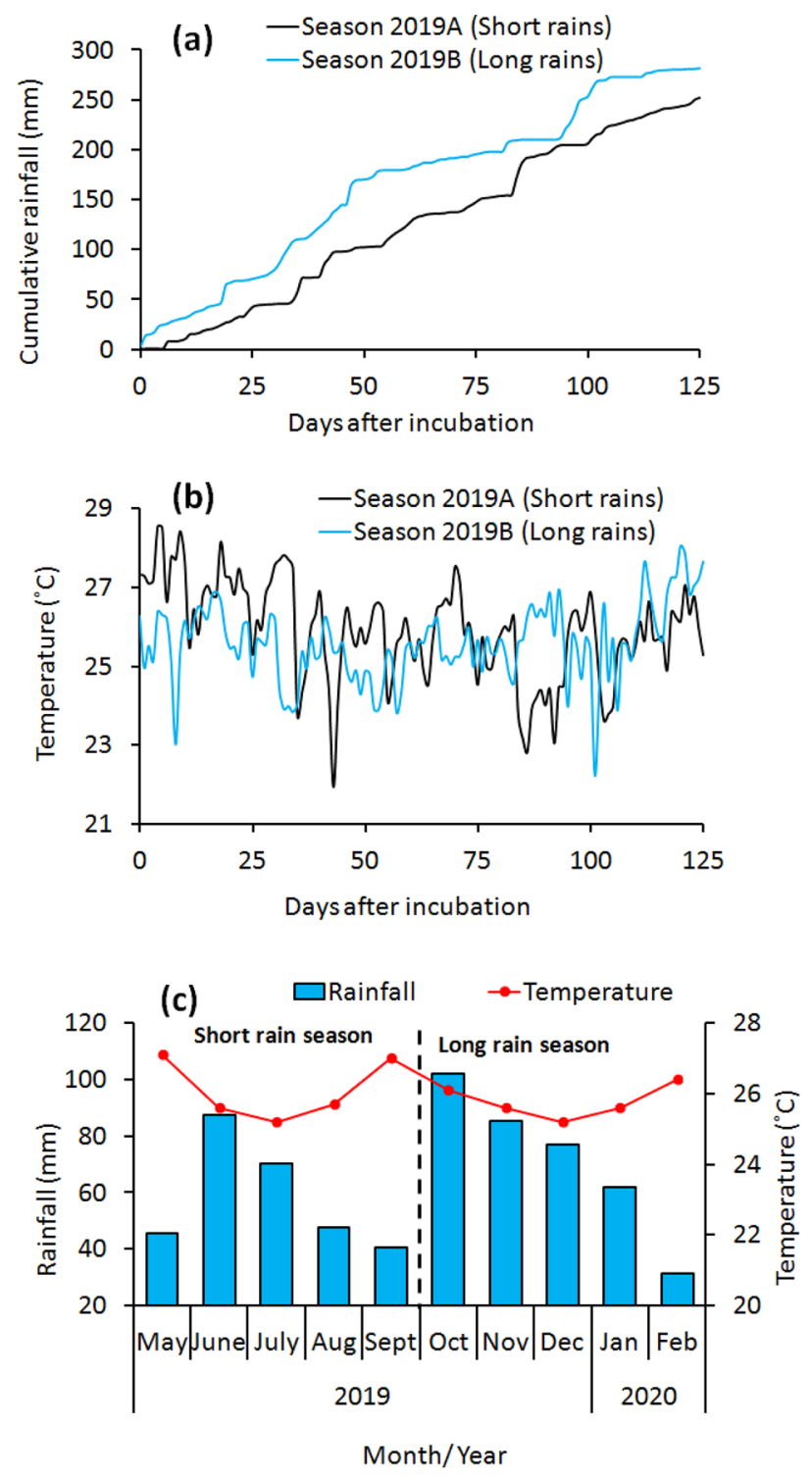

Figure 3. Cumulative rainfall (a), daily temperature (b) and monthly rainfall and temperature (c) during experiments.

The current study revealed higher nutrients concentrations (Fig. 3 and Table 3). Nutrient release (Table 4) in fertilizer amended soils compared to unfertilized soil is consistent with previous studies that reported the resultant effect of low soil fertility in Kenya ${ }^{3,52,53}$ and most countries in SSA ${ }^{1,2}$. It recommended regular fertilizer inputs for soil fertility improvement ${ }^{23,54-56}$. Therefore, the application of high-quality fertilizers (such as the BSFFF) can improve soil health and crop productivity ${ }^{20,21}$ by increasing the availability of nutrients (such as nitrogen and phosphorus), which are the most limiting nutrients to crop production in $\mathrm{SSA}^{2}$.

The amount of $\mathrm{N}$ released using BSFFF was higher than that achieved using farmyard manure and tithonia in the soils of central Kenya ${ }^{57}$. The higher concentrations and nutrients release capacity associated with BSFFF could be attributed to the good quality of the fertilizer and its high mineralization rate, as previously reported ${ }^{27}$. The increased phosphorus availability achieved in soil treated with BSFFF could be partly attributed to the high soil $\mathrm{pH}$ values (8.0-8.9) (Fig. 1a,d) that do not favour P fixation, which is common in the acidic soils of Kenya ${ }^{52,53}$ and SSA $^{2}$. Acidic soils $(<\mathrm{pH} 6)$ have high iron and aluminium oxides that react with phosphate ions to form insoluble compounds, thus reducing the quantity of $\mathrm{P}$ available for plant growth ${ }^{58,59}$. Findings from the current study concur with those of von Arb et al. ${ }^{60}$, who reported an increase of available soil P in organic farming systems of Central Kenya. Therefore, this study highlights the role of the BSFFF amendment in ameliorating $\mathrm{P}$ availability by causing a liming effect in soils with low $\mathrm{pH}$.

The high concentration and release of potassium observed in SAFI amended soil could be attributed to the initially high $\mathrm{K}$ concentration in SAFI (Table 5). This is in agreement with previous studies that reported high potassium concentration in biochar-fortified organic fertilizers ${ }^{48,61}$. Nevertheless, the quantities of potassium released by soil amended with BSFFF were sufficient to produce most cereals, legumes, and vegetable crops. 
The increased release of N, P and K observed during the long rainy season (Table 4) indicates the role of soil moisture in nutrients release from organic fertilizer. With continued application, BSFFF could be solely relied on for providing nutrients for crop production. This would save farmers from the expensive mineral fertilizer that is less effective in soils with multiple degradation challenges ${ }^{4,23}$, and cater for organic farmers who exclusively rely on organic fertilizers for crop production. Our sister paper supported this assertation, which reported higher growth, yield and nutrient uptake associated with maize grown using BSFFF compared to commercial organic (SAFI) and mineral (urea) fertilizers ${ }^{20}$.

The higher populations of soil bacteria (Fig. 1b,e) and fungi (Fig. 1c,f) achieved using BSFFF indicate that in addition to increasing nutrient supply, this frass fertilizer has the potential to increase soil microbial abundance and diversity, which is key for improving biological soil fertility. The current findings agree with previous studies that have reported the additional benefits of using insect frass fertilizer (such as increased microbial abundance and activity, deeper plant root growth and suppression of plant pathogens) $)^{9,11,12,22}$. Furthermore, the BSFFF takes a shorter time to generate ( 5 weeks) than conventional composts $(8-24 \text { weeks })^{18}$. Therefore, findings from this study are crucial in changing attitudes towards organic fertilizer use, with the advantages of higher nutrient release capacity, less bulkiness and shorter production time associated with BSFFF.

\section{Conclusion}

The current study has demonstrated that BSFFF has a high potential to supply adequate nutrients for optimal crop production. The higher ammonification and low nitrification rates indicate that nitrogen immobilization could occur at the initial stages of crop growth. Therefore, mineral $\mathrm{N}$ supplementation would be necessary to compensate for net immobilization and improve synchrony of $\mathrm{N}$ release for plant growth. Nevertheless, the increase in nutrient release and nitrification rates during the long rainy season implies that the continued application of BSFFF would increase $\mathrm{N}$ mineralization and nutrient release. The significantly higher amounts of $\mathrm{P}$ released by soil amended with BSFFF indicate its key role in enhancing P availability through its liming effect.

Furthermore, the higher population of soil bacteria and fungi associated with BSFFF amended soil underline its potential for improving biological soil fertility. Therefore, BSFFF is recommended for a sustainable enhancement of soil health and crop productivity, thus reducing overdependence on low-quality organic fertilizers and expensive mineral fertilizers. Future studies should determine mid- and long-term patterns in nutrient release, abundance, diversity and functional roles of bacteria and fungi in soils amended with BSFFF.

\section{Methods}

Description of the study site. Field experiments were set up for two seasons (April-September 2019 and October 2019-March 2020) at the Kenyatta University Teaching and Demonstration farm ( $1^{\circ} 10^{\prime} 59^{\prime \prime}$ S, 36 $55^{\prime} 34^{\prime \prime}$ E, $1580 \mathrm{~m}$ above sea level), Nairobi County, Kenya. Nairobi County receives bimodal rainfall with annual averages of $925 \mathrm{~mm}$ and mean monthly temperatures of $21-28^{\circ} \mathrm{C}$ (www. meteo.go.ke). The first rainfall season (short rains) starts from March to June, while the second season (long rains) runs from October to January. Cumulative rainfall totals of 252 and $281 \mathrm{~mm}$ were received during the short and long rainy seasons experiments, respectively (Fig. 3a). Mean monthly rainfall of 40 and $87 \mathrm{~mm}$, and $31-102 \mathrm{~mm}$ were received during the short and long rainy seasons experiments, respectively (Fig. 3c). Mean daily temperatures of $22-29^{\circ} \mathrm{C}$, and $22-28^{\circ} \mathrm{C}$ were recorded during the short and long rainy seasons, respectively (Fig. 3b). The short rainy season had higher mean monthly temperatures than the long rainy season (Fig. 3c).

Soils in the study site are Acric Ferralsols ${ }^{62}$ characterized by low organic matter, shallow depths, and low $\mathrm{pH}$ levels. Before the onset of experiments, soils were sampled $(0-20 \mathrm{~cm})$ for determination of total organic $\mathrm{N}$, total organic carbon, available phosphorus $(\mathrm{P})$, exchangeable cations [potassium $(\mathrm{K})$, calcium $(\mathrm{Ca})$, and magnesium $(\mathrm{Mg})], \mathrm{pH}$, and soil texture following procedures described by Okalebo et al. ${ }^{63}$. Table 5 presents the characteristics of the experimental soil.

Source of organic fertilizers. The experiment involved two organic fertilizers: the black soldier fly frass fertilizer (BSFFF) and commercial organic fertilizer (SAFI). The BSFFF was a product obtained from the feeding of BSF larvae on brewery spent grain (sourced from Kenya Breweries Limited, Nairobi) at the Animal Rearing and Quarantine Unit of the International Centre of Insect Physiology and Ecology (icipe), Nairobi. The BSF larvae were reared in metallic trays using a rearing substrate hydrated to approximately $70 \pm 1 \%$ moisture content, following procedures described by Beesigamukama et al. ${ }^{18}$. The frass obtained was composted inside a greenhouse using the heap method. During composting, frass heaps of $1 \mathrm{~m}$ height and $4 \mathrm{~m}$ long were built on surfaces lined with polythene sheets and hydrated to $55-65 \%$ moisture content. After 5 weeks, a mature and stable frass product was obtained and used in the experiments as BSFFF. Details of the entire composting process up to the compost maturity stage are described in our sister paper $^{21}$.

The SAFI was sourced from Safi Organics Limited (http://safiorganics.co.ke/) located in Mwea town, Kirinyaga County, Kenya. It was a mixture of composted chicken manure, biochar, and rock phosphate. Table 5 presents selected physical-chemical characteristics of the organic fertilizers used in the experiments.

Experimental set up. This study was carried out alongside agronomic experiments aimed at determining the nitrogen fertilizer equivalence value of BSFFF and synchrony of $\mathrm{N}$ release for maize production ${ }^{21}$. The BSFFF and SAFI were applied at rates of 0 and $5 \mathrm{tha}^{-1}$, according to an organic fertilizer rate that had been previously used in central Kenya ${ }^{31,57,64}$. Thus, parallel experiments were carried out for a period equivalent to two maize cropping seasons (April-September 2019 and October 2019-March 2020) to investigate the ammonification and nitrification processes, rates of $\mathrm{N}$ mineralization and nitrification, and the quantities of nutrients released by soil amended with BSFFF and SAFI. 
Soil sampling and incubation. From each plot, the soil was collected from 0 to $20 \mathrm{~cm}$ depth before applying organic fertilizers. The soil was manually sorted to remove objects, stones, and clods bigger than $2 \mathrm{~mm}$. The soil was then homogenized by hand mixing in a basin. The two organic fertilizers were separately mixed with the soil at the rate of $5 \mathrm{t} \mathrm{ha}^{-1}$. The moisture content of the mixture (soil-organic fertilizer) was adjusted to $60 \%$ soil water holding capacity using distilled water. Two hundred grams of the mixture were placed in an air-permeable ziplock bag sealed to prevent water entry and nutrient loss ${ }^{36,40}$. The ziplock bags were buried at $10-20 \mathrm{~cm}$ depth in respective plots in the field. At the same time, $200 \mathrm{~g}$ of unamended soil from each plot (as control) were placed in ziplock bags and buried at the same depths $(10-20 \mathrm{~cm})$ in each of the respective plots.

Five bags were randomly buried per replicate, giving a total of 15 bags per treatment at the beginning of each cropping season. The bags were retrieved at 15, 30, 70, 91, and 125 days of incubation corresponding to seedling, vegetative, tasseling, silking, and harvesting stages of the maize crop growth. The positions of the bags were marked using pegs to avoid disturbance during weeding and for easy retrieval. The retrieved bags were labelled on each sampling date, placed in airtight polythene bags, and carried in a cool box containing ice blocks to reduce microbial activities during transportation. The samples were used to determine soil mineral $\mathrm{N}$ (ammonium and nitrate) concentration, $\mathrm{pH}$, fungi and bacterial populations, and other nutrient concentrations.

Nitrogen mineralization. The concentrations of nitrate $\left(\mathrm{NO}_{3}{ }^{-1}\right)$ and ammonium $\left(\mathrm{NH}_{4}{ }^{+}\right)$in unamended soil and soil amended with organic fertilizers were used to calculate $\mathrm{N}$ mineralization and nitrification rates at each sampling time using Eqs. (1) and $(2)^{40}$. The nitrification ratio was calculated by dividing the concertation of ammonium ( $\left.\mathrm{mg} \mathrm{kg}^{-1}\right)$ at each sampling period by concentrating nitrate $\left(\mathrm{mg} \mathrm{kg}^{-1}\right)$ during the same period.

$$
\begin{gathered}
\text { Nitrogen mineralization rate }\left(m g N g^{-1} d a y^{-1}\right)=\frac{\left[N O_{3}^{-}+N H_{4}^{+}\left(m g g^{-1}\right) t_{i+k}-N O_{3}^{-}+N H_{4}^{+}\left(m g g^{-1}\right) t_{i}\right]}{t_{i+k}-t_{i}} \\
\text { Nitrification rate }\left(m g N g^{-1} d a y^{-1}\right)=\frac{\left[N O_{3}^{-}\left(m g g^{-1}\right) t_{i+k}-N O_{3}^{-}\left(m g k g^{-1}\right) t_{i}\right]}{t_{i+k}-t_{i}}
\end{gathered}
$$

where, $t_{i}$ represents sampling times $i=0,1,2,3, \ldots \mathrm{t}_{\mathrm{i}+\mathrm{k}}$ is $t_{i}$ plus time $k$ intervals where $k=1,2,3,4, \ldots$

Nutrient released by unamended soil and soils amended with organic fertilizers. The concentrations of nutrients $(\mathrm{N}, \mathrm{P}, \mathrm{K}, \mathrm{Ca}$, and $\mathrm{Mg}$ ) released by unamended soil and soil amended with organic fertilizers at the maturity stage (125th day of incubation) of each cropping season were used to calculate the cumulative quantities of nutrients released throughout the maize growing season. The amounts of nutrients (N, P, K, Ca, and $\mathrm{Mg}$ ) released were expressed on a $\mathrm{kg}$ per hectare basis using Eq. (3). The amount of $\mathrm{N}$ released was computed using the mineral $\mathrm{N}$ (ammonium and nitrate) data.

$$
\text { Nutrient released }\left(\mathrm{kg} \mathrm{ha}^{-1}\right)=\frac{\text { nutrient concentration }\left(\mathrm{mg} \mathrm{kg}^{-1}\right) \times \text { mass of soil layer }(\mathrm{kg})}{1,000,000}
$$

where, mass of soil layer $(\mathrm{kg})=$ soil bulk density $\left(\mathrm{kgm}^{-3}\right) \times \operatorname{volume}$ of soil layer $\left(\mathrm{m}^{3}\right)$

$$
\text { volume of soil layer }\left(\mathrm{m}^{3}\right)=\text { area of one hectare }\left(\mathrm{m}^{2}\right) \times \text { depth of soil layer }(m)
$$

Laboratory analysis methods. The $\mathrm{pH}$ and electrical conductivity (EC) were determined using extracts of 1:10 and 1:2.5 (w/v) for organic fertilizer to distilled water and soil to distilled water, respectively. The contents were then shaken for $1 \mathrm{~h}, 180$ revolutions $\mathrm{min}^{-1}$, on an orbital and linear shaker (MI0103002, Foure's Scientific, Guangdong, China). Then, the $\mathrm{pH}$ and $\mathrm{EC}$ were read directly using a $\mathrm{pH}$ (AD1000, Adwa, Bucharest, Romania) and EC meter (AVI, Labtech, Mumbai, India), respectively Okalebo et al. ${ }^{63}$.

The mineral N (nitrate and ammonium) was extracted from organic fertilizers and soil using $0.5 \mathrm{M}$ potassium sulphate at a ratio of $1: 10(\mathrm{w} / \mathrm{v})$. The nitrate and ammonium concentrations in solutions after filtration were determined by colourimetric methods at 419 and $655 \mathrm{~nm}$, respectively, as described by Okalebo et al. ${ }^{63}$. The populations of soil bacteria and fungi were determined by culturing using nutrient agar for bacteria and potato dextrose agar for fungi. The number of colony-forming units (CFU) per treatment were counted after 24-48 h, and data were expressed as $\mathrm{CFU} \mathrm{g} \mathrm{g}^{-1}$. Total organic carbon of organic fertilizers and soil was determined using the wet oxidation method ${ }^{65}$.

The total N, P, K, Ca, and Mg of organic fertilizers were extracted using the acid digestion method ${ }^{63}$. From this extract, total N, P, and $\mathrm{K}$ were determined using the Kjeldahl digestion and distillation method $^{66}$, UV-Vis spectrometry ${ }^{63}$, and flame photometry ${ }^{63}$, respectively. The total Ca and $\mathrm{Mg}$ concentrations were determined using atomic absorption spectrometry (AAS) ${ }^{63}$ at 422.7 and $285.2 \mathrm{~nm}$, respectively (iCE 3300 AA system, Thermo Scientific, Shanghai, China). Available $\mathrm{P}$ and exchangeable $\mathrm{Ca}$ and $\mathrm{Mg}$ in soil were determined using Bray $2^{63}$ and AAS, respectively, while exchangeable $\mathrm{K}$ was determined using flame photometry. Total $\mathrm{N}$ in soil was determined using Kjeldahl digestion and distillation $\operatorname{method}^{66}$, while soil texture and bulk density determined using the Bouyoucos and core sampling methods, respectively ${ }^{63}$.

Data analysis. Before statistical analysis, data were tested for normality using the Shapiro-Wilk test. Analysis of variance tests was performed on data on soil $\mathrm{pH}$ and concentrations of ammonium, nitrate, nutrients ( $\mathrm{N}, \mathrm{P}$, 
$\mathrm{K}, \mathrm{Ca}, \mathrm{Mg}$ ), fungi, and bacteria using a linear mixed-effect model with "lmer" function from the package "lme4". Fertilizer treatments and incubation time were kept as fixed effects, whereas replication was a random effect. Data on amounts of nutrients were analyzed using a one-way analysis of variance test. Computation of least squares means was done using "lsmeans" package, followed by mean separation using adjusted Tukey's method implemented using "cld" function from the "multicompView" package. Data were analyzed separately for each season. All the statistical analyses were conducted using R software version 3.6.0 ${ }^{67}$.

\section{Data availability}

All relevant data are presented in the paper.

Received: 1 April 2021; Accepted: 6 July 2021

Published online: 20 July 2021

\section{References}

1. Wortmann, C. S. et al. Diagnosis of crop secondary and micro-nutrient deficiencies in sub-Saharan Africa. Nutr. Cycl. Agroecosyst. 113, 127-140 (2019)

2. Tully, K., Sullivan, C., Weil, R. \& Sanchez, P. The state of soil segradation in sub-Saharan Africa: Baselines, trajectories, and solutions. Sustainability 7, 6523-6552. https://doi.org/10.3390/su7066523 (2015).

3. Muchena, F. N., Onduru, D. D., Gachini, G. N. \& de Jager, A. Turning the tides of soil degradation in Africa: Capturing the reality and exploring opportunities. Land Use Policy 22, 23-31 (2005).

4. FAO. The State of Food and Agriculture. Leveraging Food Systems for Inclusive Rural Transformation. www.fao.org/publications. https://doi.org/10.2307/2938399 (2017)

5. Rusinamhodzi, L., Corbeels, M. \& Giller, K. E. Diversity in crop residue management across an intensification gradient in southern Africa: System dynamics and crop productivity. Food Crop. Res. 185, 79-88 (2016).

6. Rufino, M. C. et al. Competing use of organic resources, village-level interactions between farm types and climate variability in a communal area of NE Zimbabwe. Agric. Syst. 104, 175-190 (2011).

7. Ndambi, O. A., Pelster, D. E., Owino, J. O., de Buisonjé, F. \& Vellinga, T. Manure management practices and policies in Sub-Saharan Africa: Implications on manure quality as a fertilizer. Front. Sustain. Food Syst. 3, 1-14 (2019).

8. Menino, R. et al. Agricultural value of Black Soldier Fly larvae frass as organic fertilizer on ryegrass. Heliyon 7, e05855 (2021)

9. Houben, D., Daoulas, G., Faucon, M. P. \& Dulaurent, A. M. Potential use of mealworm frass as a fertilizer: Impact on crop growth and soil properties. Sci. Rep. 10, 1-9 (2020).

10. Klammsteiner, T., Turan, V., Juárez, M.F.-D., Oberegger, S. \& Insam, H. Suitability of black soldier fly frass as soil amendment and implication for organic waste hygienization. Agronomy 10, 1578 (2020)

11. Quilliam, R. S. et al. Integrating insect frass biofertilisers into sustainable peri-urban agro-food systems. J. Insects Food Feed 6, 315-322 (2020).

12. Poveda, J. et al. Mealworm frass as a potential biofertilizer and abiotic stress tolerance-inductor in plants. Appl. Soil Ecol. 142, 110-122 (2019).

13. Kagata, H. \& Ohgushi, T. Positive and negative impacts of insect frass quality on soil nitrogen availability and plant growth. Popul. Ecol. 54, 75-82 (2012).

14. Lalander, C. et al. Faecal sludge management with the larvae of the black soldier fly (Hermetia illucens): From a hygiene aspect. Sci. Total Environ. 458-460, 312-318 (2013).

15. Lalander, C. H., Fidjeland, J., Diener, S., Eriksson, S. \& Vinnerås, B. High waste-to-biomass conversion and efficient Salmonella spp. reduction using black soldier fly for waste recycling. Agron. Sustain. Dev. 35, 261-271 (2015).

16. Erickson, M. C., Islam, M., Sheppard, C., Liao, J. \& Doyle, M. P. Reduction of Escherichia coli O157:H7 and Salmonella enterica serovar Enteritidis in chicken manure by larvae of the black soldier fly. J. Food Prot. 67, 685-690 (2004).

17. Lalander, C. et al. Fate of pharmaceuticals and pesticides in fly larvae composting. Sci. Total Environ. 565, 279-286 (2016).

18. Beesigamukama, D. et al. Low-cost technology for recycling agro-industrial waste into nutrient-rich organic fertilizer using black soldier fly. Waste Manag. 119, 183-194 (2021).

19. Oonincx, D. G. A. B., van Huis, A. \& van Loon, J. J. A. Nutrient utilisation by black soldier flies fed with chicken, pig, or cow manure. J. Insects Food Feed 1, 131-139 (2015).

20. Beesigamukama, D. et al. Exploring black soldier fly frass as novel fertilizer for improved growth, yield, and nitrogen use efficiency of maize under field conditions. Front. Plant Sci. 11, 1-17 (2020).

21. Beesigamukama, D. et al. Nitrogen fertilizer equivalence of black soldier fly frass fertilizer and synchrony of nitrogen mineralization for maize production. Agronomy 10, 1-9 (2020).

22. Choi, S. \& Hassanzadeh, N. BSFL Frass: A novel biofertilizer for improving plant health while minimizing environmental impact. Can. Sci. Fair J. 2, 41-46 (2019).

23. Vanlauwe, B. et al. Integrated soil fertility management in sub-Saharan Africa : Unravelling local adaptation. Soil J. 1, 491-508 (2015).

24. Kihara, J. et al. Understanding variability in crop response to fertilizer and amendments in sub-Saharan Africa. Agric. Ecosyst. Environ. 229, 1-12 (2016).

25. Loecke, T. D., Cambardella, C. A. \& Liebman, M. Synchrony of net nitrogen mineralization and maize nitrogen uptake following applications of composted and fresh swine manure in the Midwest U.S. Nutr. Cycl. Agroecosyst. 93, 65-74 (2012).

26. Bowden, C., Spargo, J. \& Evanylo, G. Mineralization and $\mathrm{n}$ fertilizer equivalent value of composts as assessed by tall fescue (festuca arundinacea). Compos. Sci. Util. 15, 111-118 (2007).

27. Adin Yéton, B. G. et al. Decomposition and nutrient release pattern of agro-processing by-products biodegraded by fly larvae in Acrisols. Arch. Agron. Soil Sci. 65, 1-12 (2019).

28. Osterholz, W. R., Rinot, O., Liebman, M. \& Castellano, M. J. Can mineralization of soil organic nitrogen meet maize nitrogen demand?. Plant Soil 415, 73-84 (2017).

29. Cai, A. et al. Carbon and nitrogen mineralization in relation to soil particle-size fractions after 32 years of chemical and manure application in a continuous maize cropping system. PLoS ONE 11, 1-14 (2016).

30. Friedel, J. K., Herrmann, A. \& Kleber, M. Ion exchange resin-soil mixtures as a tool in net nitrogen mineralisation studies. Soil Biol. Biochem. 32, 1529-1536 (2000).

31. Musyoka, M. W. et al. Nitrogen release and synchrony in organic and conventional farming systems of the Central Highlands of Kenya. Nutr. Cycl. Agroecosyst. 113, 283-305 (2019).

32. Li, L. \& Li, S. Nitrogen mineralization from animal manures and its relation to organic N fractions. J. Integr. Agric. 13, 2040-2048 (2014).

33. Alizadeh, P., Fallah, S. \& Raiesi, F. Potential N mineralization and availability to irrigated maize in a calcareous soil amended with organic manures and urea under field conditions. Int. J. Plant Prod. 6, 493-512 (2012). 
34. Kaleem Abbasi, M. \& Khaliq, A. Nitrogen mineralization of a loam soil supplemented with organic-inorganic amendments under laboratory incubation. Front. Plant Sci. 7, 1-9 (2016).

35. Wang, C. et al. Soil gross $\mathrm{N}$ ammonification and nitrification from tropical to temperate forests in eastern China. Funct. Ecol. 32, 83-94 (2018).

36. Pinto, R., Brito, L. M. \& Coutinho, J. Nitrogen mineralization from organic amendments predicted by laboratory and field incubations. Commun. Soil Sci. Plant Anal. 51, 515-526 (2020).

37. Cusick, P. R., Powell, J. M., Kelling, K. A., Hensler, R. F. \& Muňoz, G. R. Dairy manure N mineralization estimates from incubations and litterbags. Biol. Fertil. Soils 43, 145-152 (2006).

38. Breuillin-Sessoms, F. et al. Nitrification gene ratio and free ammonia explain nitrite and nitrous oxide production in urea-amended soils. Soil Biol. Biochem. 111, 143-153 (2017).

39. Johnson, H. J., Colquhoun, J. B., Bussan, A. J. \& Laboski, C. A. M. Estimating nitrogen mineralization of composted poultry manure, organic fertilizers, and green manure crops for organic sweet corn production on a sandy soil under laboratory conditions. HortTechnology 22, 37-43 (2012).

40. Gómez-Muñoz, B., Hinojosa, M. B. \& García-Ruiz, R. In situ net N mineralisation and nitrification under organic and conventionally managed olive oil orchards. Nutr. Cycl. Agroecosyst. 101, 223-239 (2015).

41. Beesigamukama, D. et al. Biochar and gypsum amendment of agro-industrial waste for enhanced black soldier fly larval biomass and quality frass fertilizer. PLoS ONE 15, e0238154 (2020).

42. Fornara, D. A. et al. Plant effects on soil $\mathrm{N}$ mineralization are mediated by the composition of multiple soil organic fractions. Ecol. Res. 26, 201-208 (2011).

43. Bernal, M. P., Alburquerque, J. A. \& Moral, R. Composting of animal manures and chemical criteria for compost maturity assessment. A review. Bioresour. Technol. 100, 5444-5453 (2009).

44. Liang, Y., Leonard, J. J., Feddes, J. J. R. \& McGill, W. B. Influence of carbon and buffer amendment on ammonia volatilization in composting. Bioresour. Technol. 97, 748-761 (2006).

45. Sánchez, O. J., Ospina, D. A. \& Montoya, S. Compost supplementation with nutrients and microorganisms in composting process. Waste Manage. 69, 136-153 (2017).

46. Tarre, S. \& Green, M. High-rate nitrification at low pH in suspended- and attached-biomass reactors. Appl. Environ. Microbiol. 70, 6481-6487 (2004).

47. StLuce, M., Whalen, J. K., Ziadi, N. \& Zebarth, B. J. Nitrogen Dynamics and Indices to Predict Soil Nitrogen Supply in Humid Temperate Soils (Elsevier Inc, 2011).

48. Sanchez-Monedero, M. A. et al. Role of biochar as an additive in organic waste composting. Bioresour. Technol. 247, 1155-1164 (2018).

49. Kimetu, J. M. et al. Nitrogen fertilizer equivalencies of organics of differing quality and optimum combination with inorganic nitrogen source in Central Kenya. Nutr. Cycl. Agroecosyst. 68, 127-135 (2004).

50. Rovira, P. \& Vallejo, V. R. Labile and recalcitrant pools of carbon and nitrogen in organic matter decomposing at different depths in soil: An acid hydrolysis approach. Geoderma 107, 109-141 (2002).

51. Kleber, M. What is recalcitrant soil organic matter?. Environ. Chem. 7, 320-332 (2010).

52. Keino, L. et al. Nutrients limiting soybean (glycine max l) growth in acrisols and ferralsols of Western Kenya. PLoS ONE 10, 1-20 (2015).

53. Gachimbi, L. N. et al. Nutrient balances at farm level in Machakos (Kenya), using a participatory nutrient monitoring (NUTMON) approach. Land Use Policy 22, 13-22 (2005).

54. Tittonell, P., Corbeels, M., Van Wijk, M. T., Vanlauwe, B. \& Giller, K. E. Combining organic and mineral fertilizers for integrated soil fertility management in smallholder farming systems of Kenya: Explorations using the crop-soil model FIELD. Agron. J. 100, 1511-1526 (2008).

55. Rufino, M. C. et al. Manure as a key resource within smallholder farming systems: Analysing farm-scale nutrient cycling efficiencies with the NUANCES framework. Livest. Sci. 112, 273-287 (2007).

56. Tittonell, P., Vanlauwe, B., Corbeels, M. \& Giller, K. E. Yield gaps, nutrient use efficiencies and response to fertilisers by maize across heterogeneous smallholder farms of western Kenya. Plant Soil 313, 19-37 (2008).

57. Musyoka, M. W., Adamtey, N., Muriuki, A. W. \& Cadisch, G. Effect of organic and conventional farming systems on nitrogen use efficiency of potato, maize and vegetables in the Central highlands of Kenya. Eur. J. Agron. 86, 24-36 (2017).

58. Kisinyo, P. O. et al. Phosphorus sorption and lime requirements of maize growing acid soils of Kenya. Sustain. Agric. Res. 2, 116 (2013).

59. Ch' Ng, H. Y., Ahmed, O. H. \& Majid, N. M. A. Improving phosphorus availability, nutrient uptake and dry matter production of Zea mays L. on a tropical acid soil using poultry manure biochar and pineapple leaves compost. Exp. Agric. 52, 447-465 (2016).

60. von Arb, C. et al. Soil quality and phosphorus status after nine years of organic and conventional farming at two input levels in the Central Highlands of Kenya. Geoderma 362, 114112 (2020).

61. Awasthi, M. K. et al. Heterogeneity of biochar amendment to improve the carbon and nitrogen sequestration through reduce the greenhouse gases emissions during sewage sludge composting. Bioresour. Technol. 224, 428-438 (2017).

62. Gachene, C. \& Kimaru, G. Soil Fertility and Land Productivity: A Guide for Extension Workers in the Eastern Africa Region (2003).

63. Okalebo, J. R., Kenneth, W. G. \& Woomer, P. L. W. Laboratory Methods of Soil and Plant Analysis: A Working Manual 2nd edn. (SACRED Africa, 2002).

64. Mucheru-Muna, M. et al. Enhancing maize productivity and profitability using organic inputs and mineral fertilizer in central Kenya small-hold farms. Exp. Agric. 50, 250-269 (2014).

65. Nelson, D. W. \& Sommers, L. E. Total carbon, organic carbon, and organic matter. Methods of soil analysis Part 2: Chemical and microbiological properties. Am. Soc. Agron. 9, 539-579 (1982).

66. Jackson, M. L. Soil Chemical Analysis 498 (Prentice Hall of India Pvt. Ltd., 1973)

67. R Core Team. R: A Language and Environment for Statistical Computing (R Foundation for Statistical Computing, 2019).

\section{Acknowledgements}

We are grateful for the financial support provided by the Canadian International Development Research Centre (IDRC) and the Australian Centre for International Agricultural Research (ACIAR) (INSFEED-Phase 2: Cultivate Grant No: 108866-001), Norwegian Agency for Development Cooperation, the Section for research, innovation, and higher education grant number RAF-3058 KEN-18/0005 (CAP-Africa), the Netherlands Organization for Scientific Research, WOTRO Science for Global Development (NWO-WOTRO) (ILIPA-W 08.250.202), and The Rockefeller Foundation (SiPFeed-2018 FOD 009) through the International Centre of Insect Physiology and Ecology (icipe). We also gratefully acknowledge the support of the icipe core funders the United Kingdom's Foreign, Commonwealth \& Development Office (FCDO); the Swedish International Development Cooperation Agency (Sida); the Swiss Agency for Development and Cooperation (SDC); the Federal Democratic Republic of Ethiopia; and the Government of the Republic of Kenya. The views expressed herein do not necessarily reflect 
the official opinion of the donors. The senior author, Dennis Beesigamukama, was financially supported by the German Academic Exchange Service (DAAD) In-Region Postgraduate Scholarship. The authors would like to thank Faith N. Wamurango, Shem Ondiaka, Joshua Wambua, Isaiah E. Rachami, Kennedy K. Kiprotich, and Mathew K. Theuri for providing technical support during data collection.

\section{Author contributions}

D.B., B.M., N.K., C.J.G., S.S. and C.M.T. conceived the experiments, D.B., B.M., C.J.G., N.K. and C.M.T. conducted the experiments, D.B. and C.M.T., analysed the results. All authors reviewed the manuscript.

\section{Competing interests}

The authors declare no competing interests.

\section{Additional information}

Correspondence and requests for materials should be addressed to D.B. or C.M.T.

Reprints and permissions information is available at www.nature.com/reprints.

Publisher's note Springer Nature remains neutral with regard to jurisdictional claims in published maps and institutional affiliations.

(c) (i) Open Access This article is licensed under a Creative Commons Attribution 4.0 International

License, which permits use, sharing, adaptation, distribution and reproduction in any medium or format, as long as you give appropriate credit to the original author(s) and the source, provide a link to the Creative Commons licence, and indicate if changes were made. The images or other third party material in this article are included in the article's Creative Commons licence, unless indicated otherwise in a credit line to the material. If material is not included in the article's Creative Commons licence and your intended use is not permitted by statutory regulation or exceeds the permitted use, you will need to obtain permission directly from the copyright holder. To view a copy of this licence, visit http://creativecommons.org/licenses/by/4.0/.

(C) The Author(s) 2021 